\title{
STICKY INTUITIONS AND THE FUTURE OF SEXUAL ORIENTATION DISCRIMINATION
}

\author{
Suzanne B. Goldberg
}

As once-accepted empirical justifications for discriminating against lesbians and gay men have fallen away, the major stumbling block to equality lies in a set of intuitions, impulses, and so-called common sense views regarding sexual orientation and gender. This Article takes up these impulses and views, which I characterize as "sticky intuitions," to consider both their sustained influence and the prospects for their destabilization. In this effort, I first offer a framework for locating the intuitions' work within contemporary doctrine, culture, and politics. I then advance an extended typology of the intuitions themselves, drawing from case law, scholarly literature, and public discourse. Although the individual intuitions will not surprise those familiar with the field, their amalgamation into a typology sheds light on their synergies as well as the complex nature of their influence.

After describing these entangled intuitions, I offer several provisional observations regarding intuitions' influence on lawmaking generally. I then raise what is likely to be a critical question going forward: In an era in which courts and legislatures continue to sustain sexual orientation discrimination, despite empirical data negating any legitimate basis for the embraced distinctions, how much candor ought there be in challenges to judicial and public squeamishness about homosexuality and gender roles? Cognitive theorists offer helpful insights, although operationalizing what we know about altering intuitions may be particularly difficult in the litigation context. Still, there are a number of options that warrant continued consideration by both theorists and strategists in the field.

INTRODUCTION.

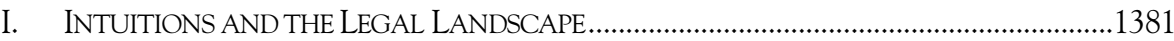

A. Explicit Sexual-Orientation-Based Distinctions .......................................................1382

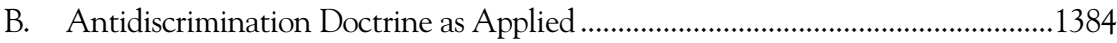

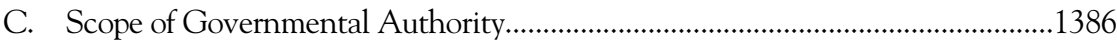

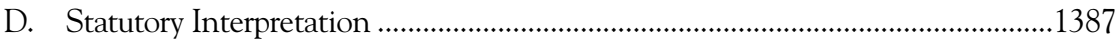

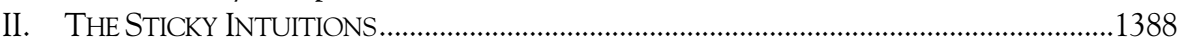

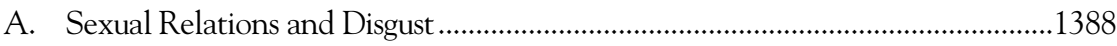

* Many thanks to Vince Blasi, Mary Anne Case, Jack Greenberg, Terry Maroney, Henry Monaghan, Melissa Murray, Nancy Polikoff, Wil Waluchow, and the Sexuality and Gender Law: Assessing the Field, Envisioning the Future UCLA Law Review/Williams Institute Symposium participants. Special thanks for excellent research assistance to Taylor Kirklin and Shawn Kravich, as well as to Amy McCamphill and Natalie Moore. 


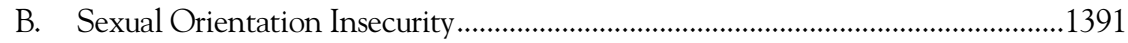

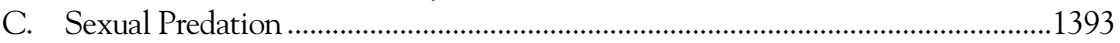

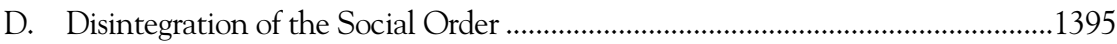

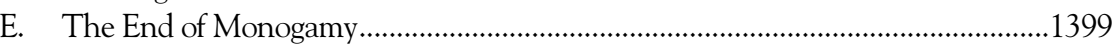

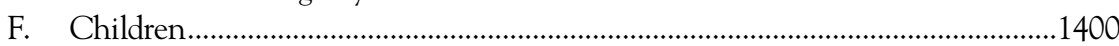

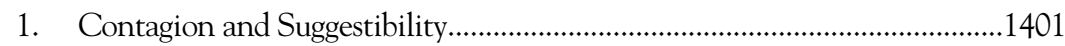

2. Shifting Morality …………………………………….............................1402

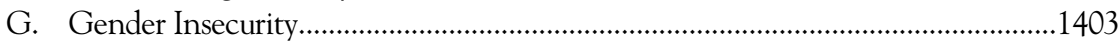

III. THEORIZING THE LEGAL WORK OF INTUITIONS ...........................................................1404

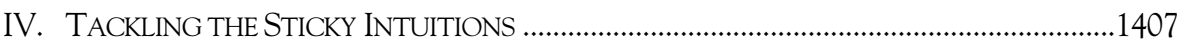

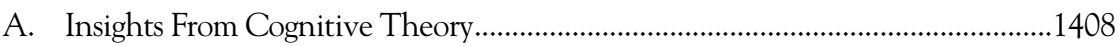

B. From Cognitive Theory to Practice...................................................................1410

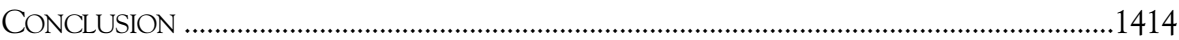

\section{INTRODUCTION}

When the U.S. Supreme Court upheld Georgia's sodomy law in 1986 and declared Michael Hardwick's constitutional privacy claim "at best, facetious," many condemned the decision as amounting to a gay exception to the U.S. Constitution. ${ }^{2}$ At that time, several lines of privacy law suggested that the state could not criminalize the private, noncommercial sexual intimacy of consenting adults, ${ }^{3}$ yet a majority of the Court found that body of law largely irrelevant to Hardwick's claim that the Constitution shielded him from arrest for engaging in consensual sexual activity, in his bedroom, with another man. ${ }^{4}$

During the almost quarter-century since Bowers v. Hardwick was decided, momentum has shifted markedly, with gay and lesbian litigants increasingly winning their claims. ${ }^{6}$ Most striking, perhaps, is the Supreme Court's about-face in Laurence v. Texas, in which the Court not only reversed its earlier Bowers

1. Bowers v. Hardwick, 478 U.S. 186, 194 (1986).

2. See, e.g., JOYCE MURDOCH \& DEB PRICE, COURTING JUSTICE: GAY MEN AND LESBIANS V. THE SUPREME COURT 334 (2001).

3. See, e.g., Griswold v. Connecticut, 381 U.S. 479, 486 (1965) (recognizing married couples' privacy right to access and use contraception and declaring the state's restriction on contraception to be "repulsive to the notions of privacy surrounding the marriage relationship"); Eisenstadt v. Baird, 405 U.S. 438, 452 (1972) (extending Griswold and holding that the state's purported interest in deterring fornication was not a sufficient interest to justify restricting unmarried individuals' access to birth control).

4. Bowers, 478 U.S. at 190.

5. 478 U.S. 186.

6. See, e.g., Lawrence v. Texas, 539 U.S. 558, 559-60 (2003) (invalidating Texas's "homosexual conduct" law); Romer v. Evans, 517 U.S. 620, 621 (1996) (striking down a state constitutional amendment that banned antidiscrimination protections for gay people); Goodridge v. Dep't of Pub. Health, 798 N.E.2d 941. 969 (Mass. 2003) (recognizing same-sex couples' right to marry).

7. 539 U.S. 558 . 
decision but also declared that Bowers was "not correct when it was decided" and is "not correct today." Dramatic, too, was the 6-3 ruling in Romer v. Evans," in which the Court invoked an important race discrimination opinionJustice Harlan's dissent in Plessy v. Ferguson ${ }^{10}$ - to reinforce its decision that a state constitutional amendment barring antidiscrimination protection for gay people violated the Constitution's Equal Protection Clause. ${ }^{11}$ And of course there are a handful of state high court rulings authorizing marriage equality, ${ }^{12}$ as well as lesser known but also influential victories won by gay youth challenging abuse at school ${ }^{13}$ and lesbian and gay parents seeking parental rights, ${ }^{14}$ among others.

Yet even with these advances, a Bowers-like gay exceptionalism continues to repeat itself at both the state and federal level in courts around the country, where the extant doctrine appears to support whatever gay rights claim is at issue, but courts nonetheless find a way to reject the claim. ${ }^{15}$ We see this exceptionalism outside the litigation context as well, where public officials and voters promote and support restrictions on the rights of gay people, often in the marriage, family law, and education settings, ${ }^{16}$ even while the surrounding law

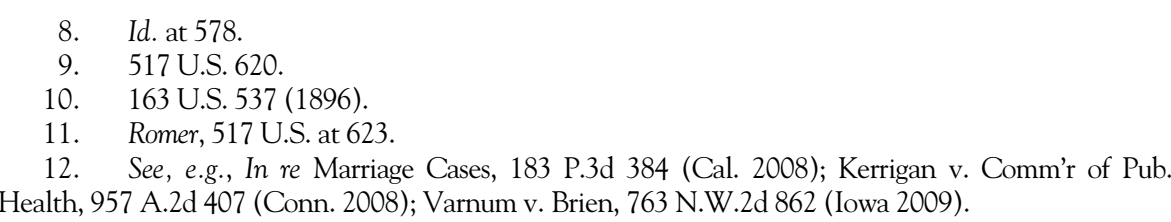

13. See, e.g., Nabozny v. Podlesny, 92 F.3d 446 (7th Cir. 1996). For additional discussion of Nabozny, see infra notes 38-41 and accompanying text.

14. See, e.g., Elisa B. v. Superior Court, 117 P.3d 660, 670 (Cal. 2005) (holding that a child may have two mothers under the Uniform Parentage Act and that both can be required to pay child support); In the Matter of Jacob, 660 N.E.2d 397, 398 (N.Y. 1995) (authorizing second-parent adoption of a child parented by two mothers); In re custody of H.S.H.-K., 533 N.W.2d 419, 437 (Wis. 1995) (applying an equitable test to recognize parental rights of a lesbian functional parent).

15. See, e.g., Lofton v. Sec'y of Dep't of Children \& Family Servs. (Lofton I), 358 F.3d 804, 827 (11th Cir. 2004) (sustaining Florida's bar on adoption of children by gay adults); State v. Limon, 83 P.3d 229, 240 (Kan. Ct. App. 2004) (upholding age-of-consent rules that punished same-sex relationships more severely than different-sex relationships), rev'd, 122 P.3d 22 (Kan. 2005); Hernandez v. Robles, 855 N.E.2d 1, 7 (N.Y. 2006) (relying on "[i]ntuition and experience" regarding childrearing to sustain the state's exclusion of same-sex couples from marriage); cf. Lewis v. Harris, 908 A.2d 196, 200 (N.J. 2006) (refusing to recognize a marriage right for same-sex couples despite a substantial body of state law rejecting sexual-orientation-based distinctions).

16. See, e.g., Richard Salas, In re Marriage Cases: The Fundamental Right to Marry and Equal Protection Under the California Constitution and the Effects of Proposition 8, 36 HASTINGS CONST. L.Q. 545 (2009) (examining California's Proposition 8); Rachel Simmonsen, Judge Tosses Lawsuit Over Gay Club at Okeechobee High, PALM BEACH POST, Apr. 10, 2008, available at http://www.palmbeachpost.com/ treasurecoast/content/tcoast/epaper/2008/04/10/0410ogay.html?cxntlid=inform_sr (discussing school officials' efforts to ban a gay-straight alliance organization at Okeechobee, FL high school); Adam Pertman, Election Day Robbery, ARKANSAS TIMES, Jan. 15, 2009, available at http:// www.arktimes.com/Articles/ArticleViewer.aspx?ArticleID=838aea86-83a5-498c-a7d84ec62f96e303 
and much of the relevant data indicate that these restrictions are unjustified and possibly impermissible. ${ }^{17}$

Thus, although today's legal landscape might appear to be stunningly positive to a gay rights supporter from the 1950 s, or even the $1980 \mathrm{~s},{ }^{18}$ more needs to be known about why judges, legislators, and other decisionmakers continue to promote and sustain restrictions on the rights of lesbians and gay men, especially in light of the changes over time. ${ }^{19}$ As is often the case with restrictions imposed on social groups, the underlying reasons for much contemporary discrimination against lesbians and gay men today have relatively little to do with what is actually articulated either in judicial opinions or by legislators in debate. ${ }^{20}$

(reporting on the effects of an Arkansas referendum prohibiting adoption by gay and lesbian prospective parents).

17. The starkest illustration of this point may be California's Proposition 8, which revoked marriage rights from same-sex couples by popular vote after the California Supreme Court determined that the denial of marriage rights violated the state constitution. See CAL. CONST. art. I, § 7.5 ("Only marriage between a man and a woman is valid or recognized in California."); Strauss v. Horton, 207 P.3d 48, 59 (Cal. 2009) (describing the legal context surrounding Proposition 8's passage); cf. In re Marriage Cases, 183 P.3d 384 (Cal. 2008) (invalidating California's exclusion of same-sex couples from marriage based on the state constitution's due process and equal protection guarantees).

Similarly, courts have repeatedly rebuffed efforts by universities and school districts to forbid meetings of gay student organizations or gay-straight alliances. See, e.g., Gay Students Org. of the Univ. of N.H. v. Bonner, 509 F.2d 652 (1st Cir. 1974); Colin ex rel. Colin v. Orange Unified Sch. Dist., 83 F. Supp. 2d 1135 (C.D. Cal. 2000); Gay-Straight Alliance of Yulee High Sch. v. Sch. Bd., 602 F. Supp. $2 d$ 1233 (M.D. Fla. 1974).

Professional organizations have participated in both public debates and litigation to reinforce that an individual's sexual orientation does not determine parenting ability. See, e.g., Brief for Am. Psychological Ass'n et al. as Amici Curiae Supporting Plaintiffs-Respondents, Hernandez v. Robles, 855 N.E.2d 1 (N.Y. 2006) (No. 86), 2006 WL 1930166; Am. Acad. of Pediatrics, Co-Parent or Second-Parent Adoption by SameSex Parents, 109 PEDIATRICS 339 (2002); see generally Gregory M. Herek, Legal Recognition of Same-Sex Relationships in the United States: A Social Science Perspective, 61 AM. PsYCHOLOGIST 607 (2006).

18. See, e.g., PATRICIA A. CAIN, RAINBOW RIGHTS: THE ROLE OF LAWYERS AND COURTS IN THE LESBIAN AND GAY CIVIL RIGHTS MOVEMENT (2000) (reviewing the trajectory of social change effected by the gay and lesbian rights movement).

19. The discussion here focuses predominantly on lesbians and gay men, rather than bisexuals, because bisexuality has rarely been the express subject of legal regulation. See Kenji Yoshino, The Epistemic Contract of Bisexual Erasure, 52 STAN. L. REV. 353, 353 (2000) (analyzing "why the category of bisexuality has been erased in contemporary American political and legal discourse"). Likewise, although several of the intuitions addressed in this Article implicate the legal status of transgender individuals, there are also significant doctrinal and sociopolitical differences in the legal and social statuses of gay and transgender people that warrant extended discussion beyond the scope of this Article. Rather than engage in a strained merger of ideas in the face of these differences, I suggest that both the convergences and divergences of intuitions and their influence are ripe for a separate inquiry. Cf. Taylor Flynn, Transforming the Debate: Why We Need to Include Transgender Rights in the Struggles for Sex and Sexual Orientation Equality, 101 COLUM. L. REV. 392, 392 (2001) (observing that "jurisprudence that adopts more accurate and multifaceted understandings of sex and gender," including jurisprudence particular to transgender individuals, can have a substantial positive impact on the lives of lesbians and gay men).

20. See generally Suzanne B. Goldberg, Constitutional Tipping Points: Civil Rights, Social Change, and Fact-Based Adjudication, 106 COLUM. L. REV. 1955 (2006) (analyzing the ways in which courts reason via facts about social groups while leaving unacknowledged the normative underpinnings of their decisions). 
Instead, the major stumbling block to the treatment of sexual orientation as a source of benign variation among people is a set of intuitions, impulses, instincts, and so-called commonsense views regarding sexual orientation and gender, which I collectively characterize here as "sticky intuitions" ${ }^{21}$ because of the way they have maintained their influence well after being undermined by both data and shifts in societal views. Legal doctrine remains relevant, of course, but less as a force that exposes actual rationales and more as a frame that constrains or facilitates the intuitions' operationalization. The project of understanding and diminishing the legal significance of sexual orientation thus requires navigation of this dynamic relationship between sticky intuitions and doctrine.

In this Article, I examine, from three perspectives, the sustained influence of intuitions on the rights of lesbians and gay men and the prospects for destabilizing those intuitions going forward. First, I categorize the four basic types of cases and debates where the rights of gay people are at issue. While cases abound that nominally involve gay rights, only a subset turns directly on the question whether governments and private actors may subject gay people to discriminatory treatment. In the rest, intuitions regarding homosexuality and gay people may be operative, but are often obscured by the way in which the issues are framed. Thus, the point here is to understand more clearly the locations from which intuitions exert influence.

Second, against that background, I set out the intuitions that I contend are at work. I suggest that although disgust and fear of contagion are often cited as the primary explanations for hostility toward homosexuality, the set of sentiments that contributes to the validation of restrictions on gay people's rights today is more complexly constituted. More specifically, a variety of views regarding homosexuality, gender roles, and sexuality more generally, as well as a range of views regarding the role of government, enable sexual-orientationbased discrimination to continue today. Although few of these views will come as a surprise to scholars and advocates, their amalgamation in a typology, together with illustrations from case law, public campaigns, and related matters, sheds new light on their overlap and synergies as well as the complex nature of their influence. ${ }^{22}$

21. For discussion of my broad use of "intuition," see infra note 23 and accompanying text.

22. The discussion here concentrates primarily, though not exclusively, on intuitions related to sexuality and gender. For elaboration of concerns about government action in this arena, see, for exam ple, Melissa Murray, Marriage Rights and Parental Rights: Parents, the State, and Proposition 8, 5 STAN. J. C.R. \& C.L. 357 (2009) (describing the Proposition 8 campaign to ban marriage for same-sex couples in California as focused on "state infringement of the rights of the [nongay] polity"); Richard Posner, Should There Be Homosexual Marriage? And If So, Who Should Decide?, 95 MiCH. L. REV. 1578, 1585 (1997) 
Part III of the Article considers the difficult choices associated with responses to the intuitions' continuing power. I focus particularly on one of the thorniest questions going forward: Given that the intuitions underlying contemporary sexual-orientation-based distinctions lack empirical support, how much candor ought there be about them, from both advocates and courts? To think through this question, I turn to cognitive theorists and others whose work focuses on both how we develop our intuitions and how we alter them.

I must acknowledge at the outset that my use of the word "intuition" stretches the conventional scope of the word, which is typically understood to refer to a "knowing or sensing without the use of rational processes." 23 As the typology indicates, my aim is to capture a wide range of nonanalytically derived beliefs that develop through a diverse array of belief systems. ${ }^{24}$ Thus, while some of these beliefs might be differentiated from a fine-grained understanding of intuition, the point here is to cast a wide net and gather together the set of views that, though rarely surfaced, are often deeply held and significantly influential in sexual-orientation-related decisionmaking.

Further, this project is not one in which I can prove definitively that the intuitions discussed here are actually driving the continued power of sexualorientation-based distinctions in law. Because they are often inchoate or unanalyzed by those who invoke them, these intuitions typically go unmentioned or undefended in court decisions and unelaborated in public debates. Yet, as I argue here, because the empirical and doctrinal rationales for sustaining gay/nongay classifications have fallen away, we must look beyond what is articulated explicitly and consider the unstated assumptions at work.

(stating, with respect to marriage rights for same-sex couples, that "it is a mistake to suppose that legal reasoning alone can underwrite so profound a change in public policy").

23. THE AMERICAN HERITAGE DiCTIONARY OF THE ENGLISH LANGUAGE 947 (3d ed. 1992). More elaborately, scholars describe intuition as "a cognitive process that somehow produces an answer, solution, or idea without the use of a conscious, logically defensible, step-by-step process." KENNETH R. HAMmOND, Human Judgment AND SOCIAl POlicy 60 (1996); cf. Erin Ryan, The Discourse Beneath: Emotional Epistemology in Legal Deliberation and Negotiation, 10 HARV. NEGOT. L. REV. 231, 233 (2005) (defining intuition broadly as "the mental manipulation of affective data"); R. George Wright, The Role of Intuition in Judicial Decisionmaking, 42 HoUs. L. REV. 1381, 1385 (2006) (noting that judges frequently rely on intuition in reaching legal conclusions but do not "use the term 'intuition' in rigorous, precisely defined senses").

24. Some of the sources for these views can be traced to (a) spiritual beliefs derived from a nonempirical epistemology; (b) beliefs derived from path-dependent endorsement of others' beliefs for affiliational, status, or cultural reasons; and (c) emotionally influenced beliefs reflecting involuntary reactions. Although one might be self-aware of these sources, the beliefs they produce, and the contradictory empirical evidence, the beliefs can remain difficult to dislodge and might, in that sense, be described not only as sticky intuitions but also as stubborn beliefs. I am grateful to Terry Maroney for this observation. For Maroney's thoughtful elaboration of the relationship between emotion and common sense within constitutional law, see Terry A. Maroney, Emotional Common Sense as Constitutional Law, 62 VAND. L. REV. 851 (2009). 
A last preliminary point: Some observers would argue that when courts, legislators, and voters sustain distinctions between gay and nongay people, they act on bias that must be either overcome or regulated. ${ }^{25}$ While it is likely true that courts and others sometimes cloak biases and hostility with references to intuitions, unproven assumptions, and common sense, refining our understandings of intuitions would have little payoff if this were always the case. In my view, however, treating all of these instances as reflecting the deliberate obscuring of hostility or bias is far too blunt an approach to capture the variety of instincts that lead people, including judges, to accept legal distinctions based on sexual orientation. Further, as a practical matter, pronouncements of bias may do little to shift the positions of individuals who believe they are acting rationally, as social psychologists and others have shown. ${ }^{26}$ Consequently, while ongoing work to unmask prejudices continues to be important, the field may remain unduly sticky if the grip of intuition is ignored.

\section{INTUITIONS AND THE LEGAL LANDSCAPE}

Only a subset of gay rights cases and legislative issues brings the sticky intuitions directly into play by asking, explicitly, whether gay and nongay people can reasonably be subjected to different treatment. In most other cases and debates, sexuality- and gender-related intuitions might underlie the conflict at issue, but they operate largely unacknowledged. By identifying the intuitions'

25. Cf. Marc R. Poirier, Name Calling: Identifying Stigma in the "Civil Union"|"Marriage" Distinction, 41 CONN. L. REV. 1425, 1480-81 (2009) (arguing that the distinction between civil unions and marriages should be understood against the background of antigay bias in the surrounding culture).

Related to this is the view that what sustains sexual orientation discrimination is religious belief rather than either bias or the intuitions set out below. On this point, it is certainly true that many who favor legal distinctions based on sexual orientation link their position to their religious views regarding sexuality. Cf. Frederick Mark Gedicks, Atmospheric Harms in Constitutional Law, 69 MD. L. REV. 149 (2009); see generally Andrew Koppelman, The Decline and Fall of the Case against Same-Sex Marriage, 2 U. ST. THOMAS L.J. 5 (2004). An additional factor associated with religiously based positions derives more from concerns about government infringing on individuals' ability to educate their children and otherwise act in accordance with their religious views. Cf. Answer Brief of Campaign for Cal. Families on the Merits at 23, In re Marriage Cases, 183 P.3d 384 (Cal. 2008) (No. S147999) (arguing that "preserving the definition of marriage is not about preserving a tradition of discrimination or exclusion, but about preserving the relationship upon which the future of society rests"); see generally Murray, supra note 22; Marc R. Poirier, Hastening the Kulturkampf: Boy Scouts of America v. Dale and the Politics of American Masculinity, 12 LAW \& SEXUALITY 271 (2003). Thus we see, along these lines, strong claims against antidiscrimination laws in employment, housing, and public accommodations, opposition to marriage rights for lesbian and gay couples, and resistance to school curricula that espouse respect for sexual orientation diversity.

26. See infra note 141 and accompanying text. 
whereabouts with some precision, we will be better positioned to theorize about the intuitions' visibility and resilience and how best to confront them. ${ }^{27}$

Attention to the influence of intuitions produces a different organizational scheme than the one that structures the dockets of impact litigation organizations, which divide sexual orientation discrimination cases by subject matter areas, such as family recognition, employment, law enforcement, and more. ${ }^{28}$ Here, instead, I sketch four different ways in which legal framing exposes or obscures the role of intuitions.

\section{A. Explicit Sexual-Orientation-Based Distinctions}

The first of the three categories is the most overtly evocative of intuitions. This category consists of cases and related matters in which the state has distinguished explicitly, or close to explicitly, ${ }^{29}$ between gay and nongay people. The primary, and often only, question on the table is whether the state can engage in that type of line drawing. Most litigation regarding same-sex couples' exclusion from marriage presents this question directly, as do challenges to prohibitions against gay people adopting children, bans on students' bringing a same-sex date to the prom, and the like. Because these cases expressly ask why the challenged line-drawing is permissible, they are most likely to draw out explicit discussionor at least admission — of the operative intuitions.

In a particularly striking example, the Eleventh Circuit openly acknowledged that it would rely upon its nondemonstrable and uncontestable sense of things to sustain Florida's categorical exclusion of gay adults from adopting children. $^{30}$ Under the statute at issue, every single adult who seeks to adopt a

27. Although this Article does not focus primarily on shaping doctrinal arguments to address the sticky intuitions, it bears noting that the choices among levels of scrutiny or even the quality of rational basis review can make a significant difference to the visibility and force of the intuitions in the intuitionbased cases. Because the other types of cases tend to obscure the intuitions, levels of review are somewhat less likely to be consequential in limiting the intuitions' influence on both the analysis and outcomes.

28. See, e.g., Lambda Legal, Docket, http://www.lambdalegal.org/our-work/in-court/cases/ docket.html (last visited June 4, 2010); ACLU, LGBT Discrimination, http://www.aclu.org/lgbtrights/lgbt-discrimination (click the "Cases" tab on "Related Content" header) (last visited June 4, 2010); National Center for Lesbian Rights, Case Docket, http://www.nclrights.org/site/PageServer? pagename $=$ issue_casedocket (last visited June 20, 2010).

29. Here, I mean to include rules and policies that do not refer directly to sexual orientation but have the primary consequence of burdening gay people or same-sex couples. I would put most marriage laws into this category, as they do not discriminate explicitly based on sexual orientation, but their reservation of marriage to different-sex couples has that discriminatory effect.

30. Lofton v. Sec'y of Dep't of Children \& Family Servs. (Lofton I), 358 F.3d 804, 819-20 (11th Cir. 2004). A new challenge to the law remains pending. See ACLU, In re: Gill-Case Profile, http://www.aclu.org/lgbt-rights_hiv-aids/re-gill-case-profile (last visited June 4, 2010). 
child receives an individualized assessment—unless they are gay, in which case they are banned outright from adopting. ${ }^{31}$

Rather than follow the robust empirical evidence showing that gay parents are as likely as nongay parents to raise emotionally and physically healthy children, ${ }^{32}$ the court turned to what I would characterize as a sticky intuition. Addressing the state's mother-father preference, the court wrote, "We find this premise to be one of those 'unprovable assumptions' that nevertheless can provide a legitimate basis for legislative action.",33

Intuitions and similar senses of things have also made their presence known in marriage cases, which directly pose the question whether anything about gay people could justify their exclusion from marriage. In 2006, for example, a majority of the New York Court of Appeals answered that question in this way: "Intuition and experience suggest that a child benefits from having before his or her eyes, every day, living models of what both a man and a woman are like." ${ }^{34}$

31. FLA. STAT. $\$ 63.042(3)$ (2007) (providing that "[n]o person eligible to adopt under this statute may adopt if that person is a homosexual").

32. See Lofton v. Sec'y of Dept. of Children and Family Servs. (Lofton II), 377 F.3d 1275, 1298 (11th Cir. 2004) (Barkett, J., dissenting) (stating that "many children throughout the country are lovingly and successfully cared for by homosexuals in their capacity as biological parents, foster parents, or legal guardians"); AM. PSYCHOLOGICAL Ass'N, RESOLUTION ON SEXUAL ORIENTATION, PARENTS, AND CHILDREN (2004) ("There is no scientific evidence that parenting effectiveness is related to parental sexual orientation: Lesbian and gay parents are as likely as heterosexual parents to provide supportive and healthy environments for children.").

33. Lofton I, 358 F.3d at 819-20 (quoting Paris Adult Theater I v. Slaton, 413 U.S. 49, 62-63 (1973)). By way of explanation, the court added that "[a]lthough social theorists from Plato to Simone de Beauvoir have proposed alternative child-rearing arrangements, none has proven as enduring as the marital family structure, nor has the accumulated wisdom of several millennia of human experience discovered a superior model." Id. at 820 (citing PLATO, THE REPUBLIC, at Bk. V, 459d-461e (Hackett Publ'g Co. 1992) (380 B.C.); SIMONE DE BEAUVOIR, THE SECOND SEX (H.M. Parshley ed. \& trans., Vintage Books 1989) (1949)).

34. Hernandez v. Robles, 855 N.E.2d 1, 7 (N.Y. 2006). The court added:

Plaintiffs seem to assume that they have demonstrated the irrationality of the view that opposite-sex marriages offer advantages to children by showing there is no scientific evidence to support it. Even assuming no such evidence exists, this reasoning is flawed. In the absence of conclusive scientific evidence, the Legislature could rationally proceed on the commonsense premise that children will do best with a mother and father in the home.

Id. at 84. See also Andersen v. King County, 138 P.3d 963, 983 (Wash. 2006) (plurality opinion) (sustaining Washington's ban on same-sex couples marrying in part because "children tend to thrive" in a “'traditional' nuclear family") (emphasis added). As Mary Anne Case has observed, the New York high court's acceptance of children's exposure to "living models" of men and women as a rationale for state action is also troubling because it runs contrary to the federal constitutional prohibition on embodying in law any "fixed notions concerning the roles and abilities of males and females."' Mary Anne Case, A Lot to Ask: Review Essay of Martha Nussbaum's From Disgust to Humanity: Sexual Orientation and Constitutional Law, 19 COLUM. J. OF GENDER \& L. 89, 120 (2010) (quoting Miss. Univ. for Women v. Hogan, 458 U.S. 718, 725 (1982)). 
Outside the litigation context, sticky intuitions surface most directly in public debates and voter initiatives where, as in the cases just discussed, the focus is directly on the relative worth of gay people vis-à-vis all others. So, for example, in the public discourse regarding California's Proposition 8 , the primary (though not the only) question framed for voters was whether the state should recognize gay couples' relationships via the same marriage rules as different-sex couples' relationships. ${ }^{35}$ With that opening, Proposition 8's proponents centered their campaign on claims about the dangers posed by same-sex couples and gay individuals, calling not on data but rather on voters' nonanalytical reactions to these risks. ${ }^{36}$

Yet not every case that we might think of as implicating the rights of gay people invites such open discussion regarding intuitions. In two additional categories of cases, intuitions may be very much at work but hardly at all in sight.

\section{B. Antidiscrimination Doctrine as Applied}

In the second category, the baseline question whether gay people can be subjected to different and worse treatment than nongay people is considered largely settled (with the answer being that singling out gay people for negative treatment is impermissible). At issue, instead, is whether a particular set of circumstances violates that equality premise. So, for example, within weeks after Romer v. Evans ${ }^{37}$ rejected a ban on antidiscrimination protections for gay people, the Seventh Circuit considered whether a middle school student who had been brutally harassed by his classmates for being gay and not conforming to gender norms could go to trial with a claim that his equal protection rights had been

35. See In re Marriage Cases, 183 P.3d 384, 397-98 (Cal. 2008) (framing the legal question that grew out of the initiative process as whether "our state Constitution prohibits the state from establishing a statutory scheme... under which the union of an opposite-sex couple is officially designated a 'marriage' whereas the union of a same-sex couple is officially designated a 'domestic partnership"').

36. At the hearing in Perry v. Schwarzenegger, Therese Stewart, Chief Deputy Attorney for the Plaintiff-Intervenor City and County of San Francisco, argued, "it was against this backdrop [of the history of discrimination and the demonization of gay people] that Proposition 8's proponents carefully calibrated their campaign to evoke messages that... gay relationships are inferior, that they are immoral, and that the gay agenda will have dire consequences for non-gay people, and especially for children." Transcript of Record at 47, Perry v. Schwarzenegger, No. C 09-CV-2292 (N.D. Cal. argued Jan. 11, 2010) [hereinafter Perry Transcript of Record], available at http://www.equalrightsfoundation.org/ wp-content/uploads/2010/01/Perry-Vol-1-1-11-10.pdf; see also Susan Ferriss, Couples Tell of Toll From State Gay Marriage Ban as Prop. 8 Trial Begins, SACRAMENTO BEE, Jan. 12, 2010, at A1, available at http://www.sacbee.com/politics/story/2454951.html (describing advertisements leading up to the Proposition 8 vote that suggested that marriage for gay couples is an "evil [that] must be stopped").

37. 517 U.S. 620 (1996). 
violated. $^{38}$ The court found it well-established, even then, that the Equal Protection Clause had long forbidden "'gender-based generalization[s]' in society," ${ }^{39}$ including those based on sexual orientation, and that there could be no "rational basis for permitting one student to assault another based on the victim's sexual orientation." The only question in the case, then, was whether the conduct of the school was sufficiently egregious and linked to the student's sexual orientation. ${ }^{41}$

Likewise, where a police officer threatened to disclose the sexual orientation of a young man he had arrested, the Third Circuit had little difficulty finding that a privacy right existed. "It is difficult to imagine a more private matter than one's sexuality and a less likely probability that the government would have a legitimate interest in disclosure of sexual identity," the court wrote. ${ }^{42}$ The central question, instead, was whether the officer's particular action violated the privacy right. ${ }^{43}$

Sexual harassment cases involving the targeting of gay people are similar, in that the law clearly forbids harassment based on sex. ${ }^{44}$ The debatable questions are thus not whether the law permits differentiation between gay and nongay people for purposes of harassment but rather whether the conduct at issue was because of the individual's sex and was severe and pervasive enough to meet the applicable legal standard..$^{45}$ For example, in two Ninth Circuit cases, the court had no difficulty finding that sexual harassment because of gender nonconformity and sexual harassment in a same-sex context were impermissible.

38. Nabozny v. Podlesny, 92 F.3d 446, 454-58 (7th Cir. 1996). The student brought a due process claim as well, which the court dismissed on the ground that the school had no duty under the Due Process Clause to protect him from harms caused by others. Id. at 460 .

39. Id. at 455 (quoting Weinberger v. Wiesenfeld, 420 U.S. 636, 645 (1975)).

40. See id. at 458 .

41. 'Nabozny introduced sufficient evidence to show that the discriminatory treatment was motivated by the defendants' disapproval of Nabozny's sexual orientation, including statements by the defendants that Nabozny should expect to be harassed because he is gay." Id. at 457.

The Sixth Circuit similarly found it "clearly established" that it was impermissible for the state to take a passenger from one car and put her into another, with a drunk driver who ultimately crashed and killed her, "solely for the reason that they disapproved of her perceived sexual orientation." Stemler v. City of Florence, 123 F.3d 856, 874 (6th Cir. 1997). The question, then, was whether the passenger's estate had alleged sufficient facts to show that the equal protection mandate prohibiting selective law enforcement had been violated in this particular case. Id. The court found that it had. Id.

42. Sterling v. Borough of Minersville, 232 F.3d 190, 196 (3rd Cir. 2000). See also id. ("We can, therefore, readily conclude that Wayman's sexual orientation was an intimate aspect of his personality entitled to privacy protection.").

43. Id.

44. See Oncale v. Sundowner Offshore Servs., Inc., 523 U.S. 75, 82 (1998) (holding that federal law prohibiting sex discrimination reaches same-sex sexual harassment).

45. See id. at 81 ("Whatever evidentiary route the plaintiff chooses to follow, he or she must always prove that the conduct at issue was not merely tinged with offensive sexual connotations, but actually constituted 'discrimina[tion] . . . because of ... sex."'). 
Instead, the question was whether the settled law, as applied, gave rise to actionable claims. Because the cases involved "systematic" abuse or physical abuse of a sexual nature, the court found that it did. ${ }^{46}$

Although sticky intuitions regarding gay people almost surely underlie the hostility reflected in the harassing conduct and the other acts just mentioned, the cases focus on applying existing law rather than ferreting out intuitions. As a result, this set of cases produces fewer illustrations of intuitions at work than those discussed in Part I.A, in which the central question was whether explicit sexual-orientation-based distinctions can be maintained. More importantly, it will be helpful to see that some types of cases, including these application cases, may be less affected than others by efforts to destabilize rights-blocking intuitions.

\section{Scope of Governmental Authority}

The third category encompasses matters related to the state's authority to prohibit antigay discrimination or recognize same-sex couples' relationships, and is also one in which intuitions are likely to operate below the radar. In these situations, the immediate conflict is less about the relative worth of gay people and more about the scope of a governmental unit's authority to address various forms of sexual orientation discrimination.

Consider, for example, cases that turn on whether a government official has the power to prohibit sexual orientation discrimination, which arose with some frequency during the 1980s and 1990s. In 1980, for example, New York City's mayor issued an executive order that prohibited city contractors from discriminating against employees based on sexual orientation. ${ }^{47}$ Shortly thereafter, several religiously affiliated social service providers challenged the mayor's promulgative authority. Yet discussion in the case did not elaborate upon either the organizations' reasons for wanting to retain their freedom to discriminate or the mayor's reasons for forbidding discrimination. Instead, the focus was on the mayor's authority to issue discrimination prohibitions based on traits not covered by existing law. ${ }^{48}$ A similar challenge to a 1982 New Jersey law

46. See, e.g., Rene v. MGM Grand Hotel, Inc., 305 F.3d 1061, 1068 (9th Cir. 2002) (en banc) (opining that the "physical assault of a sexual nature" by coworkers against an openly gay man amounted to a "fairly straightforward" sexual harassment case); Nichols v. Azteca Rest. Enters., 256 F.3d 864, 874-75 (9th Cir. 2001) (holding that doctrine barring sex stereotyping "squarely precludes" harassment for failure to conform to sex stereotypes).

47. See Under 21 v. City of New York, 482 N.E.2d 1, 2 (N.Y. 1985).

48. Id. at 4 (stating that "the sole issue we address is the extent of the authority in this area of the chief executive officer of the city, the Mayor, and specifically, whether the executive may forbid discrimination by city contractors on a ground not covered by any legislative enactment"). 
forbidding sexual orientation discrimination likewise focused little attention on justifications for differentiating between gay and nongay people. ${ }^{49}$ In the course of sustaining the law against a suit filed by two churches and a reverend alleging that the enactment violated their First Amendment rights, ${ }^{50}$ the Third Circuit focused largely on the contours of First Amendment overbreadth doctrine. ${ }^{51}$ It never engaged directly with the churches' views regarding the permissibility of sexual orientation discrimination. ${ }^{52}$

More recently, authority-focused challenges have targeted public officials' recognition of marriage or partnership for same-sex couples. In response to the San Francisco mayor's authorizing same-sex couples to marry, the California Supreme Court's full focus was on "an important but relatively narrow legal issue" regarding the scope of local officials' ministerial duties to enforce the state marriage law. ${ }^{53}$ Likewise, when the U.S. Supreme Court reversed a district court's decision to broadcast recordings of testimony in the Proposition 8 trial, it did not address grounds related to the worth of gay people but instead ruled entirely on the basis of the trial court's failure to follow the proper process for deviating from governing publicity rules. ${ }^{54}$

\section{Statutory Interpretation}

Like the authority cases just discussed, this category encompasses cases that, in the course of defining or interpreting a statutory term, avoid direct engagement with justifications for sexual orientation distinctions in law. In one of the earliest marriage cases, for example, a same-sex couple argued that the state's authorization of marriage reached their relationships, and the court responded by invoking the dictionary definition of marriage as between a man and a woman, as though the dictionary represented the full universe of definitional options.

\footnotetext{
49. See Presbytery of N.J. v. Whitman, 99 F.3d 101 (3d Cir. 1996).

50. Id. at 103-04.

51. The court also discussed the Pullman abstention doctrine at some length in connection with the plaintiffs' as-applied challenge. Id. at 106-07 (citing R.R. Comm'n v. Pullman, 312 U.S. 496 (1941)).

52. Id. at 105-06.

53. Lockyer v. City and County of San Francisco, 95 P.3d 459, 462 (Cal. 2004); see also Li v. State, 110 P.3d 91, 101 (Or. 2005) (rejecting county issuance of marriage licenses to same-sex couples as ultra vires).

54. Hollingsworth v. Perry, 130 S. Ct. 705, 706 (2010) (per curiam).

55. See Jones v. Hallahan, 501 S.W.2d 588, 589 (Ky. Ct. App. 1973). The court added: "It appears to us that appellants are prevented from marrying, not by the statutes of Kentucky or the refusal of the County Court Clerk of Jefferson County to issue them a license, but rather by their own incapability of entering into a marriage as that term is defined." Id.
} 
Illustrative, too, are cases in which individuals have sought standing as parents to seek custody of, or visitation with, a child they were raising with a former same-sex partner. Although many jurisdictions have moved to a functional definition of the term "parent" to determine whether an individual has standing, others have refused. Yet, while denying recognition to a child's second mother, these courts have not typically acknowledged any of the intuitions about sexuality or gender that might have influenced their interpretive move. ${ }^{56}$

In these cases, as in the application and authority cases described in Part I.B and I.C, intuitions are no doubt present, but the central question posed by the conflict does not require exposure or discussion of them.

\section{THE STICKY INTUITIONS}

Whether they are acknowledged or obscured, the intuitions I describe in this Part are, I argue, largely responsible for ongoing decisions to sustain legal distinctions based on sexual orientation. They cover a wide range, under my concededly capacious use of the word "intuition," from sentiments of disgust to fears of civilization's decline, and much in between. What they share, despite their differences, is a certain sticking power or resonance notwithstanding the absence of empirical support and, in some cases, the existence of directly contrary empirical data.

As will become apparent, many of the intuitions discussed here overlap and reinforce each other. Others are in tension. This convergence and divergence fits with my aim here, which is not to develop a pristine typology but instead to provide a heuristic for sharpening awareness of the types of intuitions potentially at work in a given setting. Ultimately, as Part III shows, observing and theorizing about the complex resistance to sexual orientation equality enables a betterpositioned perspective on the state of the law today and the prospects for change going forward.

\section{A. Sexual Relations and Disgust}

British anthropologist Mary Douglas was the first to analyze systematically the ways in which human fears of impurity, contagion, and pollution undergird

56. Compare, e.g., Alison D. v. Virginia M., 77 N.Y.2d 651, 655 (1991) (holding that "although petitioner apparently nurtured a close and loving relationship with the child, she is not a parent within the meaning of [the statute]") and Jones v. Barlow, 154 P.3d 808, 810 (Utah 2007) (refusing to grant parental status to a lesbian coparent), with, e.g., V.C. v. M.J.B., 748 A.2d 539, 554 (N.J. 2000) (according parental status to a functional lesbian parent) and In re Custody of H.S.H.-K., 533 N.W.2d 419, 437 (Wis. 1995) (same). 
social taboos. ${ }^{57}$ She identified, in particular, the ways that human beings seek to maintain the boundary between themselves and animals and elaborated the role of disgust in maintaining that boundary. ${ }^{58}$

Building on her insights, others have shown how emotions of disgust motivate adverse feelings toward sexuality, and in particular, toward sexual relations between same-sex couples. Martha Nussbaum, who has written extensively on the connection between disgust and the regulation of the rights of gay people, has observed, for example, that "the central locus of disgust in today's United States [is] male loathing of the male homosexual." the disgust triggered by sexual relations between same-sex couples to "'animalreminder' disgust ... a defense of the distinction between humans and animals."

57. MARY DOUGLAS, PURITY AND DANGER: AN ANALYSIS OF CONCEPTS OF POLLUTION AND TABOO (2003).

58. Id. at 169. Reinforcing Douglas's observations by reference to research in psychology and neuroscience, psychologist Jonathan Haidt, working with colleagues, has explained the move from concerns with purity and pollution to social norms and moral intuitions by reference to a "purity module" in the brain:

[C]ulturally widespread concerns with purity and pollution can be traced to a purity module evolved to deal with the adaptive challenges of life in a world full of dangerous microbes and parasites.... Such things, and people who come into contact with them, trigger a fast, automatic feeling of disgust. Over time, this purity module and its affective output have been elaborated by many cultures into sets of rules, sometimes quite elaborate, regulating a great many bodily functions and practices.... Once norms were in place for such practices, violations of those norms produced negative affective flashes, that is, moral intuitions.

Jonathan Haidt \& Craig Joseph, Intuitive Ethics: How Innately Prepared Intuitions Generate Culturally Variable Virtues, 133 DAEDALUS 55, 60 (2004).

59. Martha C. Nussbaum, Hiding From Humanity: Disgust, Shame, and the Law 113 (2004). Continuing the point, Nussbaum wrote:

What inspires disgust is typically the male thought of the male homosexual, imagined as anally penetrable. The idea of semen and feces mixing together inside the body of a male is one of the most disgusting ideas imaginable - to males, for whom the idea of nonpenetrability is a sacred boundary against stickiness, ooze, and death. ... Thus disgust is ultimately disgust at one's own imagined penetrability and ooziness, and this is why the male homosexual is both regarded with Id.

disgust and viewed with fear as a predator who might make everyone else disgusting.

By contrast, Nussbaum wrote that "[f]emale homosexuals may be objects of fear, or moral indignation, or generalized anxiety, but they are less often objects of disgust." Id. As discussed infra, even assuming Professor Nussbaum is correct in her differentiation of attitudes toward lesbians and gay men, a point on which I generally agree, the differentiation does not eliminate the force of other intuitions related to lesbians, as well as to lesbians and gay men collectively, in reinforcing regulations that burden gay people. On this point, see also Case, supra note 34, at 119 (stating, in connection with a review of Nussbaum's newest book on the subject, FrOM DisGUST TO HUMANITY: SEXUAL ORIENTATION AND CONSTITUTIONAL LAW (2010), that "all opposition to gay rights cannot be reduced to disgust").

60. Jonathan Haidt et al., Body, Psyche, and Culture: The Relationship Between Disgust and Morality, 9 PSYCHOL. \& DEVELOPING SOCIETIES 107, 113-15 (1997) (claiming that "most human societies place taboo on many of the possible pairings of partners (and ... sexual acts)" to establish a concrete delineation between human and animal). 
William Eskridge has described a "Constitution of (Anti-Homosexual) Disgust and Contagion" as the embodiment of these sentiments. ${ }^{61}$ To support this constitutional claim, he reviewed a range of judicial decisions sustaining restrictions on the rights of gay people, from Bowers v. Hardwick ${ }^{62}$ to numerous circuit court decisions, arguing that they can best be understood by reference to disgust toward "homosexual sex." ${ }^{63}$ Applying the disgust framework specifically to disputes regarding marriage rights, others have likewise concluded that disgust toward homosexuality lies at the root of current conflicts. ${ }^{64}$ As one scholar has written, "the moral emotion of many that homosexual behavior is disgusting and therefore immoral" drives the opposition toward marriage and parenting rights for same-sex couples.

61. William N. Eskridge, Jr., Body Politics: Lawrence v. Texas and the Constitution of Disgust and Contagion, 57 U. FLA. L. REV. 1011, 1023 (2005). Elaborating the contours of this disgust in ways similar to Nussbaum, Eskridge drew on the psychological literature just discussed, and reviewed its application to sexuality generally and to anal sex in particular.

Almost anything related to sex is disgusting to some people; some sexual practices are disgusting to almost all people; and almost all people feel their disgust intensely. Although most people engage in oral sex, and many in anal sex, a lot of Americans find these activities disgusting.... Because male homosexuality (and, quite irrationally, female homosexuality as well) is deeply associated with anal sex, it has long been disgusting to Americans. And their disgust-driven view that homosexual sex is immoral has persisted (even if at reduced levels) as the majority view during the twentieth century.

Id. (footnote omitted).

Notably, Eskridge also identified the social group associated with the despised sexual relations ("disgusting homosexual sodomites") as the targets of this jurisprudential disgust. Id. at 1013; see also Richard E. Redding, It's Really About Sex: Same-Sex Marriage, Lesbigay Parenting, and the Psychology of Disgust, 15 DUKE J. GENDER L. \& POL'Y 127, 186 (2008) ("[B]ecause they find it disgusting, many people will reject homosexuality and will not want children to be 'contaminated' by lesbigay parents."). I will return to "disgusting" actors, as distinguished from "disgusting" acts, in Part II.G infra.

62. 478 U.S. $186(1986)$.

63. See Eskridge, supra note 61; see also Redding, supra note 61, at 187 ("Gay anal sex may be an especially strong source of disgust because bodily contact with fecal material, in particular, gives rise to disgust.... 'Homophobic disgust' may then involve concerns about bodily products, such as blood and semen, and their potential for disease consequence." (quoting Bunmi O. Olatunji \& Craig N. Sawchuk, Disgust: Characteristic Features, Social Manifestations, and Clinical Implications, 24 J. SoC. \& CLINICAL PSYCHOL. 932, 946 (2005))).

64. See Marc. R. Poirier, Same-Sex Marriage, Identity Processes, and the Kulturkampf: Why Federalism Is Not the Main Event, 17 TEMP. POL. \& C.R. L. REV. 387, 414 (2008) (discussing "the dimensions of pollution claims, including moral and spiritual pollution as well as physical pollution"); Redding, supra note 61, passim. In addition, although Nussbaum has made an extended case for the elimination of disgust-based arguments from the set of permissible reasons for public persuasion, these arguments continue to be made and to exert a powerful effect in public discourse and decisionmaking. See Andrew Sullivan, Proving Animus, ATlANTIC, Jan. 14, 2010, http://andrewsullivan.theatlantic.com/the_ daily_dish/2010/01/proving-animus.html.

65. Redding, supra note 61, at 192-93. 
Related to this is the hypersexualization of gay people, relative to heterosexuals, in the public imagination. ${ }^{66}$ That is, sexual acts are often treated as the defining feature of being gay. ${ }^{67}$ To the extent that sexual acts between same-sex couples provoke disgust reactions, then, the sexualization of gay people in the public mind likely heightens the power and effect of disgust in conflicts regarding gay people's rights. ${ }^{68}$

In short, when we compile the list of intuitions and related senses of things that underlie the imposition of legal restrictions on the lives of gay people, a deep-rooted disgust toward sex acts between same-sex couples unquestionably was and still remains an important one, as the extensive discussion and documentation of it suggest.

\section{B. Sexual Orientation Insecurity}

Sexual orientation insecurity ${ }^{69}$ is closely related to disgust regarding homosexuality. Individuals who are insecure about their sexual orientation are typically discomfited not because they believe themselves to be heterosexual but rather because they feel they are not. ${ }^{70}$ And while some of that insecurity is presumably attributable to social disapprobation of gay people, some may also be associated with the sorts of disgust related to the sex acts just discussed. ${ }^{71}$

66. JONATHAN KATZ, THE INVENTION OF HETEROSEXUALITY 74 (1995) (summarizing Freud's assertion that "[a f]ully developed heterosexual is the standard against which the homosexual is always judged and found fixated").

67. See, e.g., Padula v. Webster, 822 F.2d 97, 103 (D.C. Cir. 1987) (characterizing sodomy as "the conduct that defines the class" of gay people).

68. For example, during an executive session discussing repeal of legislation granting marriage to same-sex couples in New Hampshire, State Rep. Nancy Elliot made several antigay statements about anal sex, likening it to "wriggling ... in excrement" and stating that "[t]hey" are "teaching [anal sex to fifth graders] in the public school." Nancy Elliott, Anti-Gay Lawmaker, Describes Anal Sex During Public Hearing: 'Wriggling' Around 'In Excrement', HuFFINGTON POST, Feb. 12, 2010, http://www.huffington post.com/2010/02/12/nancy-elliott-anti-gay-ne_n_460544.html; cf. James Allon Garland, Breaking the Enigma Code: Why the Law Has Failed to Recognize Sex as Expressive Conduct Under the First Amendment, and Why Sex Between Men Proves That It Should, 12 LAW \& SEXUALITY 159, 253-54 (2003) (arguing that "the popularity of the phrase 'the love that dares not speak its name' as a reference for homosexuality is just one measure of how even sexual minorities have been profoundly taught not to be comfortable verbally articulating manifestations of same-sex desire").

69. I distinguish this from insecurity about gender roles and norms, which I discuss infra Part II.G.

70. Cf. Robb Willer, Overdoing Gender: A Test of the Masculine Overcompensation Thesis 1 (unpublished paper presented at the Annual Meeting of the Am. Sociological Ass'n, 2005), available at http://willer.berkeley.edu/WillerOverdoingGender.pdf (reporting on a study in which "men given feedback threatening their masculinity ... expressed more negative attitudes towards homosexuals").

71. Again, as noted in the previous discussion, many people, gay and nongay alike, engage in the acts of oral and anal sex that provoke disgust emotions. In the public's mind, however, anal sex, in particular, is most typically associated with gay men. See supra notes 59-63 and accompanying text. 
Although sexual orientation insecurity is probably better characterized as a sense of oneself rather than as an intuition, it has a similar capacity to motivate judgments about and conduct toward others. At times, sexual orientation insecurity has been linked to bias crimes, where assailants' anxiety about their own sexual orientation motivates them to attack others they know to be gay. As one expert observed, "[b]y beating a homosexual or someone they perceive as a homosexual, they are trying to deal with their sexual insecurity." ${ }^{, 2}$ Sexual orientation insecurity has similarly been invoked in support of the gay panic defense, which, although it is now received skeptically by many courts, has a history of successful use by defendants charged with having committed a violent crime against someone of the same sex who made, or was perceived to have made, a sexual advance. ${ }^{73}$ The theory of the defense is that a sexual solicitation by someone of the same sex 'can cause a latently gay defendant to 'panic,' to become temporarily unable to distinguish right from wrong, and to severely beat or kill the solicitor." ${ }^{74}$ By invoking this defense, "the defendant claims that his culpability should be mitigated both by the fact that the victim triggered the violent reaction and by the fact that the reaction itself was uncontrollable."75

Although most individuals who are insecure about their own sexual orientation will not translate that discomfort into violent acts, it would be unreasonable to think their insecurity has no consequence whatsoever. Indeed, the theory behind the outing movement, which sought to expose as gay some elected officials who had not come out, was that the closeted individuals had allowed their insecurity about being gay to lead them to take antigay positions in public. ${ }^{76}$

A related intuition is closely tied to Mary Douglas's observations about contagion. Here, the belief is that homosexuality is something that can be

72. Lisa Gelhaus, Gay-Bashing Victims Overcome Prejudice to Win Civil Settlements, TRIAL MAG., Feb. 1, 1999, at 14, 17 (quoting bias crimes expert Brian Levin).

73. See Kara S. Suffredini, Pride and Prejudice: The Homosexual Panic Defense, 21 B.C. THIRD WORLD L.J. 279, 287 (2001). Suffredini added that the gay panic defense "has proven successful even when the victim's triggering action was as slight 'as a nonviolent verbal or gestural solicitation." Id. at 287-88 (quoting Robert G. Bagnall et al., Comment, Burdens on Gay Litigants and Bias in the Court System: Homosexual Panic, Child Custody, and Anonymous Parties, 19 HARV. C.R.-C.L. L. REV. 497, 499 (1984)).

74. Id. at 287.

75. Id. at 288 .

76. To be clear, not every political actor outed in these efforts was insecure about his sexual orientation. (I use "his" advisedly; most outing of elected officials has focused on men. In the media and entertainment worlds, women as well as men have been the target of outing campaigns.) For some of those outed, the insecurity was less about their own sexual orientation and more related to efforts to avoid public disapproval for being gay. See generally LARRY GROSS, CONTESTED ClOSETS: THE POLITICS AND ETHics of Outing (1993); Warren Johansson \& William A. Percy, Outing: SHATTERING THE CONSPIRACY OF SILENCE (1994). For one of the foundational analyses and defenses of outing, see MiCHELANGELO SIGNORILE, QUEER IN AMERICA: SEX, THE MEDIA, AND THE CLOSETS OF POWER (1993). 
caught from others or transmitted by law and the surrounding society. That is, if being gay becomes the legal and social equivalent of being heterosexual, then the intuition is that those who are currently working to keep themselves on the heterosexual side of the fence will no longer feel so constrained. ${ }^{77}$ Within this strand of thought is a distinct concern that men will no longer be as susceptible to the domesticating influence of women. ${ }^{78}$

Thus, when we consider the barriers to changing views regarding the legal relevance of sexual orientation, we ought to take into account that those who feel insecure about their sexual orientation (or the sexual orientation of others) may be especially resistant to equality claims by lesbians and gay men. ${ }^{79}$ Indeed, unlike some of the disgust intuitions described above, concerns with contagion of this sort have been directly engaged within adjudication. One staple of early custody and visitation litigation on behalf of lesbian and gay parents was addressed specifically to this point, making the argument that the sexual orientation of parents did not determine the sexual orientation of children. ${ }^{80}$

\section{Sexual Predation}

Interestingly, the intuitive link between gay men and the sexual predation of minors is one that, while powerful in past decades, appears to have weakened

77. The National Association of Research and Treatment of Homosexuality (NARTH), an organization that condones treatment to alter "unwanted homosexual attraction," alleges that the simple act of "teach[ing] our children that homosexuality is as normal and healthy as heterosexuality" may have devastating consequences:

Scientific research supports age-old cultural norms that homosexuality is not a healthy, natural alternative to heterosexuality ... It does far more harm than good to tell a teenager that his or her attractions toward members of the same sex are normal and desirable. Teens in this position need understanding and counseling, not a push in the direction of a potentially deadly lifestyle.

National Association for Research \& Therapy of Homosexuality, The Three Myths About Homosexuality, Feb. 27, 2008, http://www.narth.com/menus/myths.html.

78. See, e.g., Maggie Gallagher, What Is Marriage For? The Public Purposes of Marriage Law, 62 LA. L. REV. 773, 791 (2002) (claiming that the "larger purpose of marriage is to encourage the behavior that gives fathers to children and male support to mothers" and that the legal recognition of same-sex couples' marriages will undermine these important social needs).

79. See Transcript of Record at 387, Evans v. Romer, Civ. A. No. 92 CV 7223, 1993 WL 518586 (D. Colo. Dec. 14, 1993) (testimony of Dr. Judd Marmor) (discussing sexual orientation insecurity as a source of antigay bias).

80. See David L. Chambers \& Nancy D. Polikoff, Family Law and Gay and Lesbian Family Issues in the Twentieth Century, 33 FAM. L.Q. 523, 535 (1999) ("During the late 1970s, the first mental health research on the well-being of children raised by lesbian mothers was published. Using expert witnesses, advocates were in a better position to dispel recurring myths about lesbians as mothers-[including] that children raised by lesbian mothers would probably become gay or lesbian, would be confused about their gender identity, would be socially stigmatized, or would suffer other psychological harm." (citing Donna Hitchens \& Barbara Price, Trial Strategy in Lesbian Mother Custody Cases: The Use of Expert Testimony, 9 GOLDEN GATE U. L. REV. 451 (1978))). 
in influence in response to strong empirical evidence to the contrary. Here, the argument is that gay people (particularly men) pose a particular risk to children because their undisciplined sexuality leads them to disregard age-related norms regarding sexual relationships. ${ }^{81}$

Today, even where one might most expect to see the "gay people as sexual predators" argument, as in cases where adult-child relationships are directly at issue, the argument is not made in mainstream fora. ${ }^{82}$ Notable too is the failure of states and others to contest expert testimony on the issue. In Romer v. Evans, ${ }^{83}$ for example, an expert witness testified specifically to rebut any assumptions or intuitions about child sexual abuse being committed disproportionately by gay people, and the state of Colorado did not substantively contest her claims. ${ }^{84}$

Yet the appeal to intuitions and related fears about gay people as sexual predators has not disappeared entirely. Indeed, during California's Proposition 8 trial, one of the defendant-intervenors admitted that he had circulated a letter as part of his campaign to support the measure in which he wrote that gay people would use the right to marry as a stepping stone toward legalizing pedophilia. "On their agenda list is legalizing having sex with children," the letter claimed. ${ }^{86}$

Still, given that this argument has gone largely out of mainstream circulation, it might be instructive for those considering strategies to challenge the other, stickier intuitions to think about what prompted the shift with this one.

81. See, e.g., Paul Cameron, Family Research Inst., HomoseXuality and Child MOLESTATION, available at http://www.familyresearchinst.org/2009/02/child-molestation-andhomosexuality-2 (2009) (arguing that "the gay movement is forthright about seeking to legitimize child-adult homosexual sex" and that "there is a strong, disproportionate association between child molestation and homosexuality"); see also DEB PRICE \& JOYCE MURDOCH, COURTING JUSTICE: GAY MEN AND LeSBIANS V. THE SuPREME COURT 202 (2001) (quoting Anita Bryant's Save Our Children campaign's warning that "[t]he recruitment of our children is absolutely necessary for the survival and growth of homosexuality. Since homosexuals cannot reproduce, they must recruit, must freshen their ranks"); cf. Gregory Herek, Paul Cameron Bio and Fact Sheet, http://psychology.ucdavis.edu/rainbow/ html/facts_cameron_sheet.html (last visited June 4, 2010) (reporting that the American Psychological Association, the American Sociological Association, and other professional organizations have formally disassociated themselves from Cameron because of his misrepresentation of sexuality-related research).

82. See Boy Scouts of Am. v. Dale, 530 U.S. 640 (2000) (considering the Boy Scouts' ban on openly gay adult leaders); Lofton v. Sec'y of Dep't of Children \& Family Servs. (Lofton II), 377 F.3d 1275, 1276 (11th Cir. 2004) (evaluating Florida's ban on adoption by lesbian and gay prospective parents).

83. 517 U.S. 620 (1996).

84. Lisa KeEn \& SUZANne B. GOldBERG, Strangers tO THE LAW: GAy PEOPLE ON TRIAL 60 (1998).

85. Perry Transcript of Record, supra note 36, at 1926, available at http://www.equalrightsfoundation .org/ wp-content/uploads/2010/01/Perry-Vol-8-1-21-10.pdf (direct examination of Defendant-Intervenor Dr. Hak-Shing William Tam).

86. Id. 


\section{Disintegration of the Social Order}

In defending Britain's ban on sex between men, ${ }^{87}$ Lord Patrick Devlin gained fame, or notoriety, by claiming that maintenance of the ban was necessary to prevent the decline of civilization. ${ }^{88}$ While few today are as committed as Devlin was to the position that the disappearance of sodomy laws would destabilize civilized society, many, especially in connection with marriage, harbor deep concerns that society will suffer if homosexuality and heterosexuality are treated as legally fungible. ${ }^{89}$

Within this intuition, several concerns are arguably at work. One, which I will address in Part II.G below, is that the neutering of sexual orientation differences will also result in the neutering of gender differences. The second is linked to fears of a literal decline in civilization as a consequence of the moral failings of a society that accepts homosexuality on the same terms as heterosexuality. Think of the biblical city of Sodom, which reportedly lost all sense of restraint, including with respect to sexual relations between same-sex couples, precipitating its own destruction. ${ }^{90}$ Similarly, the dramatic decline and fall of Rome is associated in public discourse with excess and debauchery that included sexual couplings among men. ${ }^{91}$

Even if the historical record belies these associations of societal decline with the acceptance of homosexuality, there is no doubt that some powerful participants in the public discourse continue to harbor these views. Consider,

87. Offences Against the Person Act, 1861, 24 \& 25 Vict., c. 100, § 61 (Eng.) (providing that the crime of "buggery" receive a sentence of at least ten years).

88. LORD PATRICK DEVLIN, THE ENFORCEMENT OF MORALS, at vi-vii (1965).

89. Intuitions regarding the causal relationship between nondiscriminatory acceptance of homosexuality and the decline of civilization have been expressly affirmed outside the United States as well. In Uganda, for example, a conflict has roiled regarding a proposed measure that would impose severe criminal penalties, including the death penalty, on individuals found to be gay and those who have engaged in sexual relations with a same-sex partner. The proposed bill is widely regarded as supporting expansive violence against lesbians and gay men because it imposes criminal penalties on those who do not report their knowledge of "homosexual activity" within twenty-four hours. Much of the advocacy in favor of the bill has focused on the dangers that homosexuality presents to Ugandan society. See Zoe Alsop, Uganda's Anti-Gay Bill: Inspired by the U.S., TIME, Dec. 10, 2009, at 1, available at http:// www.time.com/time/world/article/0,8599,1946645,00.html.

For earlier, related concerns in the context of the threat to civilization posed by bigamy, see, for example, Reynolds v. Sims, 98 U.S. 145, 166 (1878) (advocating that limitation of marriage to two-person couples is necessary to maintain a nondespotic state).

90. See Genesis 19:1-29. I will not join the debate among religious scholars regarding what actually happened in Sodom and Gomorrah, where some have argued that the problems were not so much about sexual relations as about hostility between neighbors. For purposes here, the more important point is that, regardless of interpretive accuracy, the story of the two cities is widely seen among a broad segment of American society as a biblical rebuke of homosexuality.

91. See, e.g., JiM NELSON BLACK, WHEN NATIONS DiE (1994). 
for example, the well-publicized statements of evangelical minister Pat Robertson, who frequently preaches that tolerance of homosexuality will lead to the degradation and destruction of civilized society. ${ }^{92}$ Although these statements have been the target of criticism and ridicule, ${ }^{93}$ we would be remiss to think they have no resonance for Robertson's many followers.

In addition to concerns about catastrophic events, there exist subtler, though no less powerful intuitions regarding the mutually constitutive relationship among legal rules, moral rules, and societal well-being. Among these are fears that ending the legal privileging of heterosexuality will cause a decline in public morals that, in turn, will cause societal harm. Put another way, if the law permits same-sex couples to engage in sexual intimacy free from punishment and to marry each other on the same basis as different-sex couples, the extant moral disapproval of homosexuality will be undermined, and the surrounding society will lose its foundational moral compass. For example, the Institute for Marriage and Public Policy, an organization opposed to marriage for same-sex couples, has stated that "[w]hen family diversity moves from a principle of compassion for those in difficult circumstances, to positioning itself as a core moral ideal for family life, it fundamentally asks law and society to take the side of unencumbered adult individualism over the needs of our own children." ${ }^{94}$

A third concern draws on the ideas of John Finnis and other natural law scholars. Here the point is that there are basic human goods and acts that contribute to them, including the coupling of a married man and woman that is

92. On the Christian television program the "700 Club," Robertson said: "Sodomy-in all history, as far as I can tell, any nation that embraces this so-called 'lifestyle' and legalizes it, celebrates it, protects it is on the ash can of history. Every single one has gone into decline. There's not one that survived since this happens." 700 Club (Christian Broadcasting Network broadcast June 16, 2008). Robertson expressed similar views after Maine legalized marriage for same-sex couples in 2009:

[I]f we take biblical standards away in homosexuality, what about ... bestiality and ultimately what about child molestation and pedophilia? How can we criminalize these things and at the same time have constitutional amendments allowing same-sex marriage among homosexuals.

You mark my words, this is just the beginning in a long downward slide in relation to all the things that we consider to be abhorrent.

Pat Robertson Suggests "Ultimate Conclusion" of Legal Same-Sex Marriage Is Legal Polygamy, Bestiality, Child Molestation, Pedophilia (Christian Broadcasting Network television broadcast May 7, 2009), available at http://mediamatters.org/mmtv/200905070024.

93. See, e.g., Claire Shipman \& Devin Dwyer, White House Adviser Valerie Jarrett 'Speechless' Over Pat Robertson's Haiti Comment, ABCNEWS.COM, Jan. 14, 2010, http://abcnews.go.com/GMA/ HaitiEarthquake/white-house-advisor-valerie-jarrett-speechless-pat-robertson/story?id=9555714.

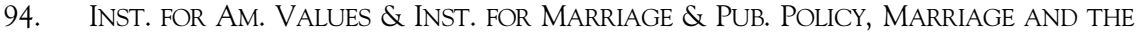
LAW: A STATEMENT OF PRINCIPLES 11 (2006), available at http://www.marriagedebate.com/pdf/ imapp.mlawstmnt.pdf. 
open to procreation. ${ }^{95}$ In this view, any acts that do not fit within the basic human goods paradigm are harmful to social welfare. To the extent the law facilitates these harmful acts, it contributes to this set of social injuries.

Along these lines, an additional concern is that full acceptance of homosexuality will destabilize the family in ways that are also harmful to civilization. Notwithstanding the growing acknowledgment that families have generally not lived up to their reputation as secure, supportive shelters from the storms of the workaday world, ${ }^{96}$ the vision of the family as a protected enclave remains powerful in many quarters. ${ }^{97}$ Although even the most traditional families have had gay members, there would be, on this view, a substantial destabilization of tradition if being gay were treated as equally praiseworthy as being heterosexual. The traditional family, with its aspirations of a mother, father, and children together as a unit secured against the world, would no longer be any more valid than the gay individual or the same-sex couple, with or without children, next door. And this shift, the intuition suggests, could cause untold harm to the social fabric. The next Subpart's discussion of the "end of monogamy" intuition is a piece of this; other concerns relate to gender role insecurity that is discussed below in Part II.G.

All of these intuitions might be described as expressing Burkean concerns about the unforeseeable consequences of social change. As Edmund Burke explained, albeit with respect to changes in political structure, there are substantial risks associated with abandoning what has been known for generations. With change that is insufficiently respectful of longstanding traditions, "the whole chain and continuity of the commonwealth [c]ould be broken. No one generation could link with the other," he wrote. ${ }^{98}$

This concern about destabilizing tradition fits directly with the Supreme Court's own jurisprudence that treats the family, and in particular, the marital couple, as a cornerstone of civilization. This view, first articulated by the Court in the late 1880s but confirmed repeatedly in recent decades, characterizes

95. See generally John M. Finnis, Law, Morality, and "Sexual Orientation", 69 NOTRE DAME L. REV. 1049 (1994).

96. See generally StEPHANIE COONTZ, THE WAY We NEVER WeRE: AMERICAN FAMILIES AND THE NOSTALGIA TRAP (1992) (advancing a critical analysis of myths about American family life).

97. See, for example, the Alliance Defense Fund's statement regarding the protection of family values: "The family is the most basic unit of any society or nation. Without healthy, functioning families, a culture cannot survive." Alliance Defense Fund, Protecting Family Values, http://www. alliancedefensefund.org/issues/traditionalfamily/Default.aspx (last visited June 20, 2010).

98. EDMUND BURKE, REFLECTIONS ON THE REVOLUTION IN FRANCE 259 (J.C.D. Clark ed., Stanford Univ. Press 2001) (1790). 
marriage as "the foundation of the family and of society, without which there would be neither civilization nor progress." ${ }^{, 9}$

For challenges to this particular intuitive link between "traditional" families and social stability, one might look, for example, to historians' engagement in the struggle for marriage equality. Their amicus briefs and testimony in marriage cases, in particular, review myriad examples of the ways in which marriage has changed over time, even while remaining a vital force in society. These submissions aim to show that changes to tradition are the norm, rather than posing the dangers the intuition would suggest. ${ }^{100}$ Their opinion essays and interventions in the public discourse have likewise sought to disrupt this intuition's power. ${ }^{101}$

Still, invocations of tradition are made regularly by both courts and others to defend the exclusion of same-sex couples from marriage as well as other restrictions on the rights of lesbians and gay men. ${ }^{102}$ And behind these invocations, presumably, is the intuition that if tradition is disregarded, civilization will suffer as a result.

99. Zablocki v. Redhail, 434 U.S. 374, 384 (1978) (quoting Maynard v. Hill, 125 U.S. 190, 211 (1888)). See also Griswold v. Connecticut, 381 U.S. 479, 496 (1965) (Goldberg, J., concurring) (describing "the traditional relation of the family" as "a relation as old and as fundamental as our entire civilization"); Skinner v. Oklahoma ex rel. Williamson, 316 U.S. 535, 541 (1942) (describing marriage and procreation as "fundamental to the very existence and survival of the race").

100. See, e.g., Brief of the Professors of the History of Marriage, Families, and the Law, Lewis v. Harris, 908 A.2d 196 (N.J. 2006) (No. A-2244-03T5); Suzanne B. Goldberg, A Historical Guide to the Future of Marriage for Same-Sex Couples, 15 COLUM. J. GENDER \& L. 249, 254-72 (2006) (presenting the historians' amicus brief in the New York marriage litigation); see also Perry Transcript of Record, supra note 36, at 220-52, available at http://www.equalrightsfoundation.org/wp-content/uploads/2010/01/ 2010-01-12-Perry-Trial-Day-02-Cott-direct-cross-redirect-Chauncey-direct-cross-mini.pdf (direct examination of Nancy Cott, testifying that marriage is constantly evolving and has changed from an institution that once embraced racial and national origin restrictions, and "restrictions on American women's citizenship rights"); id. at 440 (direct examination of George Chauncey, testifying that the "Reverend Jerry Falwell himself preached a sermon in 1958 criticizing the Supreme Court's Brown v. Board of Education decision as going against God's will and warning, actually, that it could lead to interracial marriage ....").

101. See, e.g., Stephanie Coontz, Op-Ed, Taking Marriage Private, N.Y. TimES, Nov. 26, 2007, at A23, available at http://www.nytimes.com/2007/11/26/opinion/26coontz.html?_r=1\&em\&ex=119622 $6000 \&$ en $=5 \mathrm{e} 70532 \mathrm{fce} 256 \mathrm{fe} 0 \& \mathrm{ei}=5087 \% 0 \mathrm{~A}$.

102. See, e.g., Lewis v. Harris, 908 A.2d 196, 222 (N.J. 2006) (embracing the different-sex marriage rule as "the definition that has reigned for centuries"); id. ("We cannot escape the reality that the shared societal meaning of marriage - passed down through the common law into our statutory law - has always been the union of a man and a woman. To alter that meaning would render a profound change in the public consciousness of a social institution of ancient origin."); see also Lofton v. Sec'y of Dept. of Children \& Family Servs., 358 F.3d 804, 820 (Lofton I) (11th Cir. 2004) (invoking "the accumulated wisdom of several millennia of human experience"); Brief of Defendant-Appellees with Appendix at 54, Kerrigan v. Connecticut, 957 A.2d 407 (Conn. 2008) (No. 17716) (arguing that "ii]t is entirely rational for the legislature to retain the term 'marriage' to describe the union of one man and one woman because that is the definition of marriage that has always existed in Connecticut throughout its history"); cf. Bowers v. Hardwick, 487 U.S. 186, 197 (1986) (Burger, C.J., concurring) ("To hold that the act of homosexual sodomy is somehow protected as a fundamental right would be to cast aside millennia of moral teaching."). 


\section{E. The End of Monogamy}

One particular intuition associated with the decline of civilization is that increased acceptance of homosexuality will lead to a decline in monogamous relationships. ${ }^{103}$ The underpinnings of this intuition are likely twofold. In part, there is a widespread view, confirmed by some research (and contested by other studies), that men are more inclined toward sexual promiscuity. ${ }^{104}$ This view surfaced as a partial justification for Colorado's ban on discrimination protections for gay people, with one witness highlighting the view that male couples were less likely to be monogamous in their relationships than male-female or female-female couples. ${ }^{105}$

Reinforcing this is another intuition that if the preference for heterosexuality is abandoned, nonmonogamy will be seen increasingly as a viable option. ${ }^{106}$ This is not to say that nonmonogamy is not seen as viable today, particularly for people not in committed relationships. Instead, the point here is that moving away from constraints on same-sex coupling and from marriage as it has traditionally been configured will impede the embrace of monogamy. Extending this view further, the intuition would be that without monogamy, we

103. Underlying this intuition is the assumption that monogamy is preferable to nonmonogamy. Although there have been many challenges to the desirability of monogamy, it remains the case that most people, when asked, indicate that they would prefer monogamy within long-term relationships. Justin P. Nichols, The Hidden Dichotomy in the Law of Morality, 31 CAMPBELL L. REV. 591, 606 n.114 (2009) (citing statistics that show about 60 to 70 percent of people report preferring monogamy and that there is not a significant difference in instances of monogamy based on sexual orientation). For arguments against the normative preference for monogamy, see, for example, Elizabeth F. Emens, Monogamy's Law: Compulsory Monogamy and Polyamorous Existence, 29 N.Y.U. REV. L. \& SOC. CHANGE 277 (2004); Katherine M. Franke, Theorizing Yes: An Essay on Feminism, Law, and Desire, 101 ColuM. L. REV. $181(2001)$

104. See generally Roy F. Baumeister, Kathleen R. Catanese, \& Kathleen D. Vohs, Is There a Gender Difference in Strength of Sex Drive? Theoretical Views, Conceptual Distinctions, and a Review of Relevant Evidence, 5 PeRsonAlity AND SOC. PsyChOl. Rev. 242 (2001); Dorothy Einon, Are Men More Promiscuous Than Women?, 15 ETHOLOGY \& SOCIOBIOLOGY 131 (1994).

105. See Suzanne Goldberg, Gay Rights Through the Looking Glass: Politics, Morality, and the Trial of Amendment 2, 21 FoRDHAM URB. L.J. 1057, 1078 (1994) (citing testimony of Robert Knight, Director of Cultural Research Studies at the Family Research Council).

106. See, e.g., Gallagher, supra note 78, at 790-91 ("When the law assumes and promulgates the idea that either mothers or fathers are dispensable, and that marriage is an essentially private matter whose form is determined by private adult desires, marriage in general, and children in particular, will inevitably suffer.").

In a thought experiment about society without marriage, Elizabeth Scott has explored the question whether expectations of fidelity in relationships would be as strong within civil unions as within marriage. See Elizabeth S. Scott, A World Without Marriage, 41 FAM. L.Q. 537, 563-64 (2007). 
not only risk undermining relationships, but per the discussion in Part II.D above, we also risk the decline of civilization. ${ }^{107}$

\section{F. Children}

Surely one of the stickiest and most powerful intuitions that has led decisionmakers to maintain sexual orientation's legal relevance is the sense that if there is no societal preference for heterosexuality, more children will grow up to be gay or, if not gay themselves, to have an attitude of indifference toward sexual orientation differences. Indeed, supporters of antigay measures in public initiative and referenda efforts often stress that children will be harmed if the state embraces nondiscrimination with respect to sexual orientation or does not favor heterosexuals in marriage and family law. As one advertisement used in California's Proposition 8 campaign asserted, for example, "when Massachusetts legalized gay marriage, schools began teaching second graders that boys can marry boys." ${ }^{108}$ This appeal to child-centered fears and intuitions has its roots in one of the early contemporary antigay grassroots efforts, in which Anita Bryant led the charge to repeal Dade County's sexual orientation antidiscrimination ordinance with a campaign theme of "Save Our Children."109

Similar intuitions have likely been at work where school boards have denied recognition to student organizations that seek to foster understanding and acceptance of sexual orientation differences ${ }^{110}$ and where school officials have barred students from taking a same-sex date to the school prom. ${ }^{111}$

107. The U.S. Supreme Court articulated this concern forcefully when addressing the permissibility of polygamy, describing monogamous marriage as the foundation for civilized society. Reynolds v. United States, 98 U.S. 145, 165-66 (1878) ("Upon it society may be said to be built, and out of its fruits spring social relations and social obligations and duties, with which government is necessarily required to deal. In fact, according as monogamous or polygamous marriages are allowed, do we find the principles on which the government of the people, to a greater or less extent, rests."). Invoking Professor Francis Lieber's commentary, the Court added that "polygamy leads to the patriarchal principle, and which, when applied to large communities, fetters the people in stationary despotism, while that principle cannot long exist in connection with monogamy." Id. at 166. Professor Lieber expressed this idea within the debate regarding Utah's statehood. See, e.g., Francis Lieber, The Mormons: Shall Utah Be Admitted Into the Union?, 5 PUTNAM's MONTHLY 225, 234 (1855).

108. ProtectMarriage.com, It's Already Happened, http://www.protectmarriage.com/video/view/5 (last visited June 4, 2010) (arguing that legalizing marriage for same-sex couples in California would undermine parents' rights to protect their children from certain forms of information). For additional discussion of advertising in the Proposition 8 campaign related to children and families, see generally Murray, supra note 22.

109. See Eskridge, supra note 61, at 1015-18 (providing a detailed description of Bryant's successful repeal effort).

110. See, e.g., Gay-Straight Alliance of Okeechobee High Sch. v. Sch. Bd., 483 F. Supp. 2d 1224, 1229 (S.D. Fla. 2007) (evaluating a school district's decision to prohibit the formation of a student group 
These intuitions regarding harm to children from growing up in an environment in which sexual-orientation-based distinctions are treated as legally irrelevant have numerous component parts. I will draw out several here.

\section{Contagion and Suggestibility}

Surely the disgust reaction discussed above in Part II.A, as well as fears regarding civilization's survival discussed in Part II.D, contribute to intuitive concerns about harm to children from growing up in nondiscriminatory environments. But several other intuitions may also be at work.

One is that the surrounding environment has the capacity to influence the development of children's sexual orientation. In part, the intuition is that the presence of openly gay adults might lead youth to become gay. ${ }^{112}$ A related intuition - that gay-friendly laws or communities will result in more gay youthassumes that sexual orientation is responsive to messages of acceptance or hostility from the surrounding environment. ${ }^{113}$ Some who hold this intuition no doubt believe that all gay individuals, including youth, are capable of changing their sexual orientation. ${ }^{114}$ Others focus particularly on the impressionability of

aimed at "provid[ing] a safe, supportive environment for students and to promote tolerance and acceptance of one another, regardless of sexual orientation").

111. See Kelli Gauthier, Schools Face Issue of Gay Prom Dates, CHATTANOOGA Times FreE PRESS, Apr. 25, 2009, available at http://www.timesfreepress.com/news/2009/apr/25/schools-face-issue-gay-promdates/ (discussing controversy over same-sex dates at school proms); cf. Fricke v. Lynch, 491 F. Supp. 381, 387 (D.R.I. 1980) (rejecting argument of school principal that a student's bringing a same-sex date to the school prom would cause serious disruption and harm).

112. The Kansas Court of Appeals raised a related concern in connection with the prosecution of an eighteen-year-old for engaging in consensual oral sex with a fourteen-year-old where the defendant was sentenced to 206 months rather than six months imprisonment because his sexual partner was a teenage boy rather than a teenage girl. State v. Limon, 83 P.3d 229, 232, 236, $239-40$ (Kan. Ct. App. 2004), rev'd, 122 P.3d 22 (Kan. 2005). The court wrote:

[T]raditional sexual mores have played a significant role in the sexual development of children.

During early adolescence, children are in the process of trying to figure out who they are. A part of that process is learning and developing their sexual identity. As a result, the legislature could well have concluded that homosexual sodomy between children and young adults could disturb the traditional sexual development of children.

Id. at 236. A somewhat similar role-modeling intuition led a youth organization to fire an adult leader who became pregnant out of wedlock on the theory that the leader would make the youth members more susceptible to becoming pregnant out of wedlock as well. See Chambers v. Omaha Girls Club, 840 F.2d 583 (8th Cir. 1988).

113. Another possible intuition is that hostile messages from the surrounding environment will not reshape an individual's sexual orientation but might deter a gay person from identifying as gay or entering into a same-sex partnership.

114. See, e.g., Charles W. Socarides, How America Went Gay, AMERICA, Nov. 18, 1995, at 20-22 (challenging the idea that homosexuality is innate); see also National Association for the Research \& Therapy of Homosexuality, http://www.narth.com (last visited June 4, 2010); Parents and Friends of ExGays \& Gays, http://pfox.org (last visited June 4, 2010). 
youth, ${ }^{115}$ with the accompanying intuition that these young people are more likely to become heterosexual in a world in which heterosexuality is legally and socially privileged. ${ }^{116}$

Advocates have taken up this particular intuition, typically with expert witnesses and amicus briefing from psychologists, including the American Psychological Association, to make the point that sexual orientation is set in place at an early age and is highly resistant to change. ${ }^{117}$

\section{Shifting Morality}

In addition to intuitions that youth will be influenced into becoming gay by virtue of their exposure to a gay-friendly environment, a separate, though related, intuition concerns mores and attitudes. The intuition here is that an environment that rejects discrimination against gay people will produce more people who see sexual orientation differences as benign variation rather than as a problem warranting moral disapproval and legal regulation.

Put another way, the equation of heterosexuality and homosexuality risks producing a generation at risk of losing its moral compass, on this view. In 2005, for example, the Kansas Court of Appeals upheld the application of a criminal

115. See, e.g., Parker v. Hurley, 514 F.3d 87, 100-01 (1st Cir. 2008) (noting, in the context of parents' lawsuit challenging curriculum materials aimed to encourage acceptance of gay people, that the impressionability of young children is a relevant factor); Dean v. District of Columbia, 653 A.2d 307, 353 (D.C. Cir. 1995) (describing some studies that "suggest the possibility that public policies which can be seen as positively endorsing homosexuality, in contrast with policies more clearly limited simply to forbidding discrimination against homosexuals, may have some bearing on how free an impressionable youth may feel to engage in homosexual experiences, if not to assume that orientation").

116. Along these lines, many adults, including those who oppose sexual orientation discrimination, would prefer for their children to be heterosexual, on the view that, apart from moral or religious concerns, it is easier to live as a straight person than as a gay person. While there are particular challenges associated with being a member of any minority group, including one targeted for disapproval and hostility, as gay people often are, this sense that being heterosexual equates with a better life is little more than an intuition as well. Indeed, the mainstream view of researchers is that sexual orientation is not a predictor of either happiness or mental health. See Gregory M. Herek \& Linda D. Garnets, Sexual Orientation and Mental Health, 3 ANN. REV. OF ClinICAL PSYCHOL. 353, 353-75 (2007) (examining recent empirical research on the mental well-being of gays and lesbians). Efforts to change an individual's sexual orientation from gay or bisexual to heterosexual, by contrast, have largely been associated with negative mental health outcomes. See AM. PSYCHIATRIC ASS'N, THERAPIES FOCUSED ON ATTEMPTS TO CHANGE SEXUAL ORIENTATION (2000), available at http://www.psych.org/Departments/ EDU/Library/APAOfficialDocumentsandRelated/PositionStatements/200001a.aspx (reaffirming the Association's view that "homosexuality per se is not a diagnosable mental disorder," arguing that techniques that purport to be able to change an individual's sexual orientation "are often guided not by rigorous scientific or psychiatric research," and cautioning that "anecdotal reports of 'cures' [for homosexuality] are counterbalanced by anecdotal claims of psychological harm").

117. See KeEN \& Goldberg, supra note 84, at 26; Brief of Amicus Curiae Am. Psychological Ass'n in Support of Respondent, Boy Scouts of Am. v. Dale, 530 U.S. 640 (2000) (No. 99-699), 2000 WL 339884. 
sodomy law that imposed significantly greater punishment on same-sex couples than different-sex couples. The decision, which was ultimately reversed by the Kansas Supreme Court, found that one rational basis for the law was to "protect[ ] and preserv[e] the traditional sexual mores of society and the historical sexual development of children." ${ }^{118}$

Under this kind of reasoning, even if school and youth organization leaders do not subscribe to the intuition that a youth is likely to be influenced by others toward being gay, they might well embrace sexual-orientation-based regulation as a means to preserve and reinforce their moral vision. The Boy Scouts' exclusion of openly gay leaders can be understood as reflecting these instincts, ${ }^{119}$ as can the school-based restrictions on gay-straight alliances discussed above.

\section{G. Gender Insecurity}

A final area that is rife with intuitive concerns triggered by legal regulation of sexual orientation relates to gender roles. One of these intuitions reflects a concern that if sexual orientation distinctions are disavowed by the law and surrounding society, gender differences will be next to go. In part, this sense that gay people endanger gender norms stems from the view that engaging in intimate relationships with same-sex partners is not something men or women should do. ${ }^{120}$ But gay individuals often fail to conform to gendered expectations regarding self-presentation as well. At times, there are reactions against lesbians who express themselves in nonfeminine ways, as in instances where graduating high school students have been barred from taking their class photograph in a suit or from wearing a tuxedo to a school prom. ${ }^{121}$ There are also strong reactions, sometimes bordering on disgust, toward effeminate men and boys. ${ }^{122}$ The

118. State v. Limon, 83 P.3d 229, 237 (Kan. Ct. App. 2004), rev'd, 122 P.3d 22 (Kan. 2005).

119. See Boy Scouts of Am. v. Dale, 530 U.S. 640 (2000).

120. See, e.g., Heller v. Edgewater Country Club, 195 F. Supp. 2d 1212, 1224, 1227 (D. Or. 2002) (finding sex discrimination when an employer fired a lesbian employee because she was involved in an intimate relationship with a woman, and the termination would not have taken place had the employee been involved with a man).

121. See, e.g., Lesbian Teen Sues to Force School to Hold Prom, WASH. TimES, Mar. 12, 2010, available at http://www.washingtontimes.com/news/2010/mar/12/lesbian-teen-sues-force-school-holdprom/?page $=2$ (describing school regulations forbidding students from bringing same-sex dates and forbidding girls from wearing tuxedos); Sheila Byrd, Ceara Sturgis, Lesbian High School Student, Told She Can't Wear Tuxedo in Yearbook, HuFFINGTON POST, Oct. 15, 2009, http://www.huffingtonpost.com/ 2009/10/16/ceara-sturgis-lesbian-hig_n_323968.html (reporting on an openly lesbian high school student who was prohibited from wearing a tuxedo in her school's yearbook).

122. See Mary Anne C. Case, Disaggregating Gender From Sex and Sexual Orientation: The Effeminate Man in the Law and Feminist Jurisprudence, 105 YALE L.J. 1, 26-27 (1995) (arguing that "[t]omboys are far more acceptable and unproblematic today than are sissies, who, it is still feared, are at a high risk of growing up to be homosexual or transsexual and for whom clinical treatment is more often prescribed. This is 
intuition here is that by treating sexual orientation differences as completely benign, not only will more people become gay, per the discussion above in Part II.F.1, but also more boys and men will become effeminate.

Beyond concerns with effeminacy, intuitions related to sexual orientation differences and gender insecurity can also be seen in the context of family law, where courts express concern that gay and lesbian parents will not be able to adequately instill gender differences in their children. Indeed, New York's highest court expressly included this intuition among its reasons for sustaining the exclusion of same-sex couples from marriage, citing the value to children of daily exposure to "living models of what both a man and a woman are like." Florida likewise defended its ban on adoption by gay people by claiming that dual-gender parenting plays a vital role in shaping gender identity. ${ }^{124}$ Although one might argue that the leap from ending antigay discrimination to the endangerment of gender differences gives over far too much power to the law, the intuitions are strong and influential, as these examples suggest.

\section{THEORIZING THE LEGAL WORK OF INTUITIONS}

The significant role of intuitions in sustaining legal distinctions based on sexual orientation prompts questions regarding intuitions' influence in lawmaking more generally. In this Part, I offer several provisional observations.

First are normative concerns about the power of intuitions to shape legal decisionmaking and, in particular, decisions to sustain burdens on individual rights. As we have seen, judges sometimes directly acknowledge the intuitions that shape their legal analysis; ${ }^{125}$ likewise, the public campaigns discussed above

further evidence of the disproportionate pull of gender - masculinity in a girl is approved while femininity in a boy is not only troublesome, but a marker for homosexual orientation") (footnotes omitted).

Courts are increasingly, though not uniformly, protecting transgender individuals from discrimination when the court has a sense that the new gender is fixed. See Schroer v. Billington, 577 F. Supp. 2d 293, 308 (D.D.C. 2009) (holding that "in refusing to hire [a transgender woman] because her appearance and background did not comport with the decisionmaker's sex stereotypes about how men and women should act and appear ... [the employer] violated Title VII's prohibition on sex discrimination"). But see Etsitty v. Utah Transit Auth., 502 F.3d 1215 (10th Cir. 2007) (rejecting discrimination claim brought by transgender bus driver). Courts are also increasingly protecting effeminate men from sex discrimination); cf. Nichols v. Azteca Rest. Enter., Inc., 256 F.3d 864, 875 (2001) (holding that a valid sex discrimination claim existed because the verbal abuse at issue occurred because of the plaintiffs "effeminate appearance").

123. Hernandez v. Robles, 855 N.E.2d 1, 7 (N.Y. 2006).

124. Lofton v. Sec'y of Dept. of Children \& Family Servs. (Lofton I), 358 F.3d 804, 818 (11th Cir. 2004).

125. See supra note 34 and accompanying text (discussing invocations of intuition to sustain bans on marriage and adoption by gay people). 
frame many of their messages to trigger intuitions detrimental to gay people's equality. ${ }^{126}$

The relatively open operation of these intuitions raises both moral and philosophical questions about whether decisionmaking regarding individual rights should rest on grounds that are neither demonstrable nor contestable. After all, the very essence of the intuitions is that they are not the product of a rational operation that can be subjected to the analytic scrutiny typically applied in court. ${ }^{127}$ (One might say that a certain lack of rationality accompanies most forms of public lawmaking, both in legislatures and through direct democratic action, but even in those circumstances, constitutional constraints of rationality and nonarbitrariness continue to apply.) ${ }^{128}$

If we accept that decisions regarding legal burdens rest on intuitions as much as, or more than, on rational analysis, we have also arguably acknowledged a profound institutional design defect. That is, despite our best systemic efforts to insure rigorous and well-informed decisionmaking, there are, at least in the area of sexual orientation, and I would argue also in the regulation of other vulnerable social groups, ${ }^{129}$ serious and troubling gaps in regulation.

Reliance on intuitions prompts more instrumental concerns, as well. Judge Richard Posner is helpful in illustrating the difficulty here. On the one hand, Judge Posner has affirmatively embraced intuition as an important component of good decisionmaking. Intuition, he has written, "frequently encapsulates highly relevant experience" and "produces tacit knowledge that may be a more accurate and speedier alternate in particular circumstances to analytical reasoning, even though, being tacit, it is inarticulate." ${ }^{130}$ Yet even he acknowledges, on the other hand, that the value of intuitions is limited by the experiences of the person doing the intuiting. "We must not ... suppose intuition a sure guide to sound decision making," he wrote, adding that "[a]n intuitive decision may ignore

126. See ProtectMarriage.com, supra note 108.

127. This is not to say that all intuitions are empirically untestable; some surely are.

128. See Lucas v. Forty-Fourth Gen. Assembly of Colo., 377 U.S. 713, 737 (1964) ("[T]he fact that a challenged legislative apportionment plan was approved by the electorate is without federal constitutional significance, if the scheme adopted fails to satisfy the basic requirements of the Equal Protection Clause.").

129. See generally Goldberg, supra note 20 (analyzing the gap between empirical evidence about social groups and the justifications for legal regulation of those groups).

130. Richard A. Posner, The Role of the Judge in the Twenty-First Century, 86 B.U. L. REV. 1049, 1064 (2006) (citations omitted); cf. Richard Epstein, Intuition, Custom, and Protocol: How to Make Sound Decisions With Limited Knowledge, 2 N.Y.U. J.L. \& LIBERTY 1, 12 (2006) ("II]ntuition ends up as a guide through this moral thicket, useful but limited. And in modern thought it is more likely to be displaced as two features come together: first, as the factual patterns in particular cases move further away from those that generated our bedrock intuitions, and second, as we develop more powerful functional theories. The point here is not unfamiliar-intuitions yield to protocols in many areas of life."). 
critical factors that lie outside the range of the person's experience that informs his intuition." ${ }^{131}$ Those who have reviewed the empirical literature on the relative virtues of reasoning and intuitive reasoning confirm this concern, observing that intuitions often lack reliability because they derive mainly from the necessarily limited life experiences of the individual in question. ${ }^{132}$

Further, because of their deliberately nonfalsifiable nature, intuition-based justifications for government action create greater openings than evidencebased rationales for the unfiltered influence of bias, even without the awareness of the decisionmaker him or herself. As some scholars have observed, "intuition is ... the likely pathway by which undesirable influences, like the race, gender, or attractiveness of the parties, affect the legal system."133

American philosophers have also railed against the grip of intuition on public decisionmaking. John Stuart Mill, for example, listed intuition as "one of the chief hindrances to the rational treatment of great social questions, an upholder of conservative doctrines, and one of the greatest stumbling blocks to human improvement." 134

Other philosophers, by contrast, were more sanguine about the possibility of limiting intuition's effects. As William James observed, "[r]eason, per se, can inhibit no impulses; the only thing that can neutralize an impulse is an impulse the other way." 135

James's view is reinforced by both cognitive psychologists and judges who make clear that intuition-based decisionmaking is not going anywhere. As

131. Posner, supra note 130, at 1064; see also RICHARD A. POSNER, HOW JUDGES THINK 1011 (2008).

132. See, e.g., Jonathan J. Koehler \& Daniel N. Shaviro, Veridical Verdicts: Increasing Verdict Accuracy Through the Use of Overtly Probabilistic Evidence and Methods, 75 CORNELL L. REV. 247, 271-72 (1990) (highlighting literature from fields outside law that suggest "the superiority of probabilistic methods" of reasoning). Others have identified similar challenges and perils associated with reliance on intuition in medicine. Citing a widely read medical writer's observation that "[c]ogent medical judgments meld first impressions - gestalt — with deliberate analysis," they argue that the same balance between intuition and more rigorous forms of analysis should carry over to law. Chris Guthrie, Jeffrey J. Rachlinski, \& Andrew J. Wistrich, Blinking on the Bench: How Judges Decide Cases, 93 CORNELL L. REV. 1, 43 (2007) ("Like cogent medical judgments, cogent legal judgments call for deliberation. Justice depends on it."). Cass Sunstein has made similar observations with respect to judicial reliance on heuristics more generally, which he describes as "quite valuable" in general, but also as leading, in some cases, "'to severe and systematic errors." Cass R. Sunstein, Hazardous Heuristics, 70 U. CHI. L. REV. 751, 751 (2003) (citation omitted).

133. Guthrie et al., supra note 132, at 31.

134. ROGER FRANTZ, TWO MINDS: INTUITION AND ANALYSIS IN THE HISTORY OF ECONOMIC THOUGHT 44 (2005) (describing Mill's reaction to the role of intuition in public discourse and decisionmaking).

135. Jonathan Haidt \& Fredrik Bjorklund, Social Intuitionists Answer Six Questions About Moral Psychology, in 2 MORAl Psychology: The Cognitive SCIEnCE of MORAl INTUITION AND DIVERSITY 181, 194 (Walter Sinnott-Armstrong ed., 2008) (quoting MATT RIDLEY, NATURE VIA NURTURE 39 (2004)). 
several scholars have observed, "[e]liminating all intuition from judicial decision making is both impossible and undesirable because it is an essential part of how the human brain functions." 136 And another: "In general, there is no plausible form of adjudicative absolutism that can consistently escape the need for intuitionism at some crucial point."

Yet there is little within the adjudicative, legislative, and initiative and referendum processes that acts as a check on the problems associated with the work of unfiltered intuitions. Constitutional adjudication, which has the most formalized screening process among these forms of lawmaking, typically demands only rational basis review of most decisionmaking, including sexual-orientationbased classifications in most jurisdictions. ${ }^{138}$ In the legislative and public initiative contexts, there are even fewer limits. ${ }^{139}$ And public discourse has virtually no limits at all; legislators and campaigners express their own intuitions and appeal to the intuitions (and biases) of others with regularity. ${ }^{140}$

\section{TACKLING THE STICKY INTUITIONS}

Given the institutional design that leads courts and representative bodies to review the operation of intuitions only weakly, the regulatory ball is in the advocates' court. In some respects, this regulatory work has been ongoing for many years. Amicus briefs, expert testimony, and advertising campaigns aimed directly at disrupting negative intuitions about gay people's lives and

136. Guthrie et al., supra note 132, at 5 .

137. Wright, supra note 23, at 1406; see also id. at 1384 (arguing that "intuition is invariably central — whether overtly so or not- to the process of arriving at a judicial outcome by any standard recognized means").

138. The U.S. Supreme Court has not issued a definitive pronouncement on the level of scrutiny appropriate for government action restricting the rights of gay people, although it indicated in Romer $v$. Evans that it was applying rational basis review to Colorado's gay-specific amendment. See Romer v. Evans, 517 U.S. 620, 631-32 (1996). It did not commit explicitly to a level of scrutiny in Laurence v. Texas, and the form of review applied in that case has been the subject of much debate. See Lawrence v. Texas, 539 U.S. 558, 579-80 (2003) (O'Connor, J., concurring) (discussing the standard of review when a challenged law harms a particular group); see also Laurence H. Tribe, Lawrence v. Texas: The "Fundamental Right" That Dare Not Speak Its Name, 117 HARV. L. REV. 1893, 1916-17 (2004) (describing the vague standard of review in Laurence as "bound to draw criticism and ... likely to generate confusion"). In most jurisdictions, however, courts have applied only rational basis review to sexual-orientation-based classifications. See Equal. Found. of Greater Cincinnati, Inc. v. City of Cincinnati, 128 F.3d 289, 293 n.2 (1997) (listing courts that have rejected heightened scrutiny arguments). But see In re Marriage Cases, 183 P.3d 384 (Cal. 2008) and Varnum v. Brien, 763 N.W.2d 862, 896 (Iowa 2009) (applying heightened scrutiny to state-sponsored sexual orientation discrimination).

139. For example, William Eskridge has described the campaign that led to Florida's ban on adoption by lesbians and gay men as, in part, "aggressively negative, invoking themes of disgust and contagion." Eskridge, supra note 61, at 1013.

140. See, e.g., Murray, supra note 22 (reviewing the hostile commentary toward lesbians and gay men within California's Proposition 8 campaign). 
the nature of sexual orientation are regularly introduced both in court and in the public debate.

Yet individuals often remain deeply committed to their intuitions even in the face of contrary evidence. As Dan Kahan has explained, "[r]eal-world people tend to be anti-Bayesians: rather than update their prior beliefs based on new information, they tend to evaluate the persuasiveness of new information based on its conformity to their experience." ${ }^{141}$ In other words, factual contestation, while likely helpful, may be itself insufficient to produce the destabilization necessary to unstick sticky intuitions. The question, then, is how best to marshal insights from cognitive theory and translate them into practice. This Part makes several tentative suggestions.

\section{A. Insights From Cognitive Theory}

Cognitive theory suggests at least two possible directions for challenging settled intuitions. One, which has already been integrated into advocacy efforts, draws on Gordon Allport's contact hypothesis. ${ }^{142}$ The straightforward idea is that prejudices (or, in our treatment here, negative intuitions) are best reduced by contact with the "other," which in turn leads individuals to reconceptualize, in a more positive fashion, the group category to which that "other" belongs. ${ }^{143}$

Consistent with this theory, many advocates have encouraged gay people to come out to their friends, families, neighbors, and colleagues, on the idea that knowing an actual gay person may force reconsideration of some of the intuitions outlined in Part II above, including those related to hypersexualization,

141. Dan M. Kahan, Cognitively Illiberal State, 60 STAN. L. REV. 115, 121 (2007) (footnote omitted). He adds: 'Known as 'biased assimilation,' this tendency also has a straightforward cultural explanation: ordinary persons aren't in a position to identify when new information is credible, and thus a ground for updating their prior beliefs, without recourse to the very same cultural heuristics that have generated their existing beliefs." Id. at 121-22 (footnotes omitted).

142. See generally GORDON W. AllPORT, THE NATURE OF PREJUdiCE (1954).

143. Allport's hypothesis has been elaborated by many. See, e.g., Herbert Blumer, Race Prejudice as a Sense of Group Position, 1 PAC. SOC. REV. 3, 6 (1958) (arguing that the source of racial prejudice is found in "a complicated social process in which the individual is himself shaped and organized"); Douglas H. Yarn \& Gregory Todd Jones, A Biological Approach to Understanding Resistance to Apology, Forgiveness, and Reconciliation in Group Conflict, 72 LAW \& CONTEMP. PROBS. 63, 72 n.35 (2008) (discussing work related to Allport's hypothesis). In recent years, sociologists and others have questioned some of the hypothesis's core assumptions and applications. See, e.g., H.D. FORBES, ETHNIC CONFLICT: COMMERCE, CULTURE, AND THE CONTACT HYPOTHESIS 112 (1997) (concluding that studies of proximity and prejudice "show no clear and consistent correlation between greater proximity [i.e., contact] and lower levels of prejudice"); cf. Thomas F. Pettigrew \& Linda R. Tropp, A Meta-Analytic Test of Intergroup Contact Theory, 90 J. PERSONALITY \& SOC. PSYCHOL. 751, 751 (2006) (finding that the conditions required for contact theory are not necessary for prejudice reduction). 
mentioned in Part II.A, and dangers to society, discussed in Part II.D. ${ }^{144}$ Indeed, in recent campaigns regarding marriage and other issues, advocates have also encouraged community members to come out about having gay family members and friends as well as about their support for marriage equality for same-sex couples. ${ }^{145}$ The ideas reflected in the contact hypothesis also underlie the standard approach to presenting testimony by gay people in judicial and legislative proceedings. Unlike most other forms of testimony, in which the witness moves quickly from self-introduction to the problem at hand, advocates typically encourage gay and lesbian witnesses who are testifying in the context of a sexual orientation discrimination matter to introduce themselves in depth and share their life stories, including details about their realization that they were gay and their coming out process. ${ }^{146}$

A second theory takes an even more interactive approach toward triggering new intuitions. This is the theory of role-taking, developed in the early academic literature by Robert Selman, who wrote that role-taking was important "as a critical psychological or social-cognitive skill for the growth of moral

144. See, e.g., PARENTS, FAmilies, \& Friends of LESBIANS AND Gays (PFLAG), BE YOURSELF: QUESTIONS \& ANSWERS FOR GAY, LESBIAN, BISEXUAL, AND TRANSGENDER YOUTH 11 (2006), available at http://www.pflag.org/fileadmin/user_upload/Publications/Be_Yourself.pdf ("Homophobia, biphobia and transphobia are being challenged, however, as more and more people are learning the truth about GLBT people. Attitudes are starting to change partly because GLBT people are being open and honest about who they are. Attitudes are changing also because other people are standing up with GLBT people to say, 'They are my friends, or my children, or my brothers — and I'm proud of them."'); see also David L. Chambers \& Steven K. Homer, Honesty, Privacy, and Shame: When Gay People Talk About Other Gay People to Nongay People, 4 MICH. J. GENDER \& L. 255, 255 (1997) (noting that "more and more gay people believe that the most important agent for reducing both officially sanctioned and private intolerance toward gay people is to increase the number of people known to be gay").

145. See CAROLYN WelCH GRIFFIN ET AL., BEYOND ACCEPTANCE: PARENTS OF LESBIANS AND GAYS TALK ABOUT THEIR EXPERIENCES 117-26 (1986) (describing the ability of parents of lesbians and gays to effect acceptance and tolerance by openly embracing their child's sexual orientation); see also PFLAG: Parents, Family, \& Friends of Lesbians and Gays, Coming Out Help for Friends and Families, http://community.pflag.org/Page.aspx?pid=539 (last visited June 4, 2010).

146. See, e.g., Perry Transcript of Record, supra note 36, at 77-78 (detailing the "stages" of Plaintiff Jeffrey Zarrillo's coming out history); see also id. at 152-53 (discussing the difficulties of Plaintiff Kristin Perry's need "to decide every day if [she wants] to come out"); cf. Employment Non-Discrimination Act of 2009: Hearing on H.R. 3017 Before the H. Comm. on Educ. EF Labor, 111th Cong. (2009), available at http://edlabor.house.gov/documents/111/pdf/testimony/20090923VandyBethGlennTestimony.pdf (statement of Vandy Beth Glenn, former employee of the Georgia Office of Legislative Counsel) (detailing her own coming out process: from the childhood awareness that she was a girl, to the disclosure of her gender identity to her employer who hired her when living as a man and then fired her after and because of her transition). On the theory of story-sharing in another deeply contested context, see Sarah E. Burns, Notes From the Field: A Reply to Professor Colker, 13 HARV. WOMEN's L.J. 189, 197-99 (1990) (describing the "women's voices" amicus briefs filed in cases challenging the regulation of abortion to bring before the U.S. Supreme Court the experiences of women who have had abortions). 
reasoning." 147 Here, the idea is also straightforward: "Simply by putting yourself into the shoes of another person you may instantly feel pain, sympathy, or other vicarious emotional responses."148 As psychologist Jonathan Haidt has explained, role-taking "is one of the principle pathways of moral reflection according to Piaget, Kohlberg, and other cognitive developmentalists. A person comes to see an issue or dilemma from more than one side and thereby experiences multiple competing intuitions." 149

\section{B. From Cognitive Theory to Practice}

Of course, translating these academic insights into litigation strategies and political campaigns is more than a little challenging. Not only is role-taking not standard practice in either judicial or legislative fora, but it is also difficult to imagine how, exactly, one would motivate individuals who are comfortable with their intuitions to risk destabilization in this way. Bennett Capers has suggested that one might do this in the criminal jury trial context by explicitly directing jurors to imagine the defendant as having a different sex or race as a means of "debiasing," or in the terms here, "de-intuitioning." edges, asking decisionmakers in criminal or civil litigation to imagine the parties as individuals (or entities) other than who they actually are provokes a host of constitutional concerns. ${ }^{151}$

In another context, a federal circuit judge addressing the military's sexualorientation-based exclusion of service members, asked readers to imagine heterosexuals having to change their sexual orientation. "W2 "Would heterosexuals living in a city that passed an ordinance burdening those who engaged in or desired to engage in sex with persons of the opposite sex find it easy not only to abstain from heterosexual activity but also to shift the object of their sexual desires to persons of the same sex?" he wrote, in the course of finding that the exclusion violated a gay service member's constitutional rights. ${ }^{153}$

In a more limited way than role-taking, perhaps, attention to language may do some work in bridging differences and reshaping intuitions. There have been

147. ROBERT L. SELMAN, THE PROMOTION OF SOCIAL AwARENESS 15 (2003); see also Robert Selman, The Relation of Role Taking to the Development of Moral Judgment in Children, 42 CHILD DEV. 79 (1971).

148. Jonathan Haidt, The Emotional Dog and Its Rational Tail: A Social Intuitionist Approach to Moral Judgment, 108 PSYCH. REV. 814, 819 (2001).

149. Id.; see also I. Bennett Capers, Cross Dressing and the Criminal, 20 YAlE J.L. \& Human. 1, 3-4 (2008).

150. Capers, supra note 149 , at 25 .

151. Id. at 29-30.

152. Watkins v. U.S. Army, 875 F.2d 699, 726 (9th Cir. 1989) (Norris, J., concurring).

153. Id 
deliberate rhetorical efforts in the context of sodomy law challenges to remind decisionmakers that the regulated acts at issue were not themselves homosexual and thereby to constrain the impulse toward disgust. In this regard, I think back to my own experience working on sodomy law challenges as a senior lawyer with Lambda Legal. In framing arguments, we did not use the phrases "homosexual sex" or "homosexual sodomy" that appear in so many of the discussions, both judicial and popular, regarding sodomy laws. ${ }^{154}$ Instead, we found ways to talk about "same-sex couples' sexual intimacy" or "sexual relations between same-sex couples" or other similarly wordy phrases as a way of suggesting to the court that whatever intuitions were in play should be applied to the acts at issue without regard to the sex of the couples engaging in those acts. ${ }^{155}$ We can see similar efforts today in the use of the phrase "marriage equality" and "same-sex couples' marriage rights" rather than "same-sex marriage" in an effort to reinforce that marriage itself does not have a sexual orientation. ${ }^{156}$

Outside the litigation context, there may be more room for creative strategizing, particularly with new media, to expose and disrupt settled intuitions. One approach that has proved popular, though again only with willing subjects, is the administration of the Implicit Association Test (IAT), which often alerts test takers to racial biases of which they were unaware. ${ }^{157}$ Yet without conscious, carefully constructed, and repeated efforts to "debias," the underlying intuitions may continue to do their work unfettered. ${ }^{158}$

154. See, e.g., Bowers v. Hardwick, 478 U.S. 186, 191 (1986) (ruling that there is no "fundamental right to engage in homosexual sodomy"); Christensen v. State, 468 S.E.2d 188, 195 (Ga. 1996) ("The sole basis asserted by the State in support of its sodomy statutes is its moral interest in condemning acts of homosexual sodomy.").

155. Notably, although the majority opinion in Laurence v. Texas referred to "homosexual sodomy," those references came mainly in connection with reviewing earlier cases and the historical enforcement of sodomy laws. See Lawrence v. Texas, 539 U.S. 558, 570 (2003). Toward the end of its decision, the Court wrote, instead, about "the protected right of homosexual adults to engage in intimate, consensual conduct." Id. at 576 .

156. See, e.g., Lambda Legal, Amici Curiae Brief Filed in Support of Same-Sex Couples' Right to Marry, http://www.lambdalegal.org/our-work/in-court/briefs/woo-v-california-brief-2.html (last visited June 4, 2010); see also Marc R. Poirier, The Cultural Property Claim Within the Same-Sex Marriage Controversy, 17 COLUM. J. GENDER \& L. 343, 344-45 n.3 (2008) (discussing terminological choices involved in describing marriage rights for same-sex couples).

157. See Project Implicit, https://implicit.harvard.edu/implicit (last visited June 4, 2010); see also Cass Sunstein, Some Effects of Moral Indignation on Law, 33 VT. L. REV. 405 (2009) ("The central finding [of the IAT test] is that most people show an automatic bias against African-Americans, older people, gays and lesbians, and others - even when they are unaware of it, wish to be unbiased, and indeed are stunned to see that they are automatically biased. There is evidence that people's actual behavior is sometimes affected by their automatic biases rather than by their conscious judgments."). For further discussion of implicit bias, see generally Anthony G. Greenwald \& Linda Hamilton Krieger, Implicit Bias: Scientific Foundations, 94 CAL. L. REV. 945 (2006).

158. See generally Christine Jolls \& Cass R. Sunstein, Debiasing Through Law, 35 J. LEGAL STUD. 199 (2006). 
"Old" media might also hold some potential to prompt reflection. Consider, for example, the ACLU's advertising campaign around racial profiling, which took the same facial features and, in a series of photographs, displayed them on a face with different skin colors. ${ }^{159}$ Presumably the advertising was aimed at a sort of involuntary role-taking, where the viewer of the photography would have little choice but to rethink their views regarding the significance of racial differences, at least for a moment. Conceivably, some similar creative roletaking strategies regarding sexual orientation differences could be developed for the involuntary viewer. ${ }^{160}$ Perhaps the field of subliminal messaging could also be tapped more deliberately to disrupt intuitions regarding lesbians and gay men, though these efforts have provoked controversy in other fields regarding both their use and their effectiveness and would potentially do so here as well. ${ }^{161}$

Another option, more familiar to the legal scholarship, ${ }^{162}$ would involve a move toward greater candor about the intuitions that seem to be operating in a given context. The aim would be to expose as intuitions those characterizations of lesbians and gay men that are presented as fact. So, for example, advocates might address overtly the underlying concerns with disgust, societal harm, or the shifting morality of children that they suspect are operating in the decisionmaking environment.

In theory, the approach seems to be a sensible one. If the intuitions are having an effect on decisionmaking, it seems remiss not to address them. Indeed, advocates sometimes recommend that lawyers who represent gay and transgender clients not try to hide their clients' identities for risk that the nondisclosure may leave negative intuitions regarding the client to operate unfettered, often without the decisionmaker being aware of them. ${ }^{163}$

Some debiasing efforts have been made in connection with judicial trainings, which not only supply up-to-date information regarding doctrine and relevant data related to sexual orientation but also, in some settings, encourage judges to engage in role-taking activities designed to broaden perspectives on the interaction of lesbians, gay men, and the law. See, e.g., The Williams Institute, UCLA School of Law, Judicial Training Program, http://www.law.ucla.edu/williamsinstitute/Judicial/ index.html (last visited June 4, 2010) ("provid[ing] state and federal judges with substantive training on legal issues impacting lesbian, gay, bisexual, and transgender people"); see also Nancy D. Polikoff, Educating Judges About Lesbian and Gay Parenting: A Simulation, 1 LAW \& SEXUALITY 173, 179-82 (1991) (discussing the value of simulation in judicial training regarding custody disputes involving lesbian and gay parents).

159. ACLU, Campaign Against Racial Profiling Ad, http://www.aclu.org/graphics/guilt_ad.jpg (last visited June 4, 2010).

160. See generally WiLSON BRYAN KeY, SUbliminal SEDUCTION: AD MEDia's MANiPUlation OF NOT SO INNOCENT AMERICA (1974).

161. See, e.g., John R. Vokey \& J. Don Read, Subliminal Messages: Between the Devil and the Media, 40 AM. PSYCHOL. 1231 (1985).

162. See infra note 166.

163. NAT'L CTR. FOR LESBIAN Rights, TIPS FOR LEGAL ADVOCATES WORKING WiTH LESBIAN, GAY, BISEXUAL, \& TRANSGENDER CLIENTS 1 (2007), available at http://www.nclrights.org/site/ 
Yet this approach comes with risks, too. For one, explicitly articulating the intuition might reinforce rather than disrupt it. This is particularly easy to imagine with respect to the disgust intuition discussed in Part II.A, which, if it is as primal as scholars have suggested, ${ }^{164}$ may best be overcome by leaving it unmentioned.

In addition, addressing certain wide-ranging intuitions may lead to more complications than benefits. I am thinking here of intuitions related to the effect of eliminating antigay discrimination on the public's morals and welfare, such as those discussed in Parts II.D, II.E, and II.F.2. Although advocates can, and regularly do, make claims and introduce supporting evidence regarding the harmful social consequences of discrimination, ${ }^{165}$ claims about the effect of legal change on public morality are, as noted earlier, not susceptible to evidentiarybased arguments. And indeed, where a decisionmaker might be persuaded by facts related to the harms caused by discrimination, the task of shifting views regarding the relationship between law and morality is larger and arguably more difficult.

An additional potential risk is raised by the literature on judicial candor. The debate, in essence, concerns whether candor regarding courts' decisionmaking is advisable in the name of transparency, or harmful both to judicial reasoning processes and to the judiciary's legitimacy. ${ }^{166}$ For purposes here, the central point is that candor does not necessarily produce desired outcomes, which, in this context, would be the rejection of negative intuitions about gay people. Instead, the candor literature suggests that, rather than move away from negative views, courts and others will become increasingly committed to their

DocServer/Proyecto_Poderoso_Flyer_cd.pdf?docID=2321 (arguing that advocates must "be prepared to address hostile and irrelevant arguments" pertaining to sexual orientation or gender identity). A separate but related risk is that the decisionmaker will sense that the client is hiding something, and that sense will translate to a negative judgment regarding the client's credibility. See, e.g., Cole Thaler, Representing Transgender Clients, GPSOLO, Apr./May 2007, at 52, available at http://www.abanet.org/ genpractice/magazine/2007/apr-may/transgenderclients.html (arguing that it is important to "use the correct name and pronoun [which correspond to a client's gender identity] in all pleadings, correspondence, and other documents," unless the client "might prefer that any transgender-related courtroom discussion take place at sidebar rather than in open court").

164. See supra notes 59-65 and accompanying text; see also H.A. Chapman, D.A. Kim, J.M. Susskind, \& A.K. Anderson, In Bad Taste: Evidence for the Oral Origins of Moral Disgust, 27 SCIENCE 323 (2009); cf. NUSSBAUM, supra note 59, at 3 (arguing that, as in the context of sexuality, "the disgust of a judge or jury at a murder may put the defendant into a class of especially heinous offenders").

165. Cf. David M. Huebner, Gregory Rebchook \& Susan Kegeles, Experiences of Harassment, Discrimination, and Physical Violence Among Young Gay and Bisexual Men, 94 AM. J. PUB. HEALTH 7 (2004).

166. See generally Scott Altman, Beyond Candor, 89 MiCH. L. REV. 296 (1990) (maintaining that an insistence on candor would be ill-advised because judges who are misguided may reach better decisions than judges who clearly understand their decisionmaking); Gail Heriot, Way Beyond Candor, $89 \mathrm{MICH}$. L. REV. 1945 (1991) (critiquing Altman's claims). 
intuitions and willing to rely explicitly on them. Indeed, one could put the Florida adoption and New York marriage decisions ${ }^{167}$ into this category. If courts are willing to rely openly on their own intuitions and unprovable sense of things, there is little advocates can do to overcome adverse decisions other than generally question the propriety of intuition-based decisionmaking.

\section{CONCLUSION}

As we turn toward the future of sexual orientation's legal significance, it becomes clear that negative intuitions, impulses, and instincts about lesbians and gay men loom large as barriers to equality, particularly given that empirical debates regarding sexual orientation differences are largely resolved. Although work must continue on the development of doctrinal and theoretical arguments for equality and liberty, we do ourselves a disservice by leaving these intuitions underexplored. Many difficult questions remain about the role of intuitions in decisionmaking, the reasons for their stickiness, and the strategies advocates might deploy to grapple with them. What is clear, though, is that, decades after the sticky intuitions first surfaced in gay rights conflicts, these questions are pressing, and they demand our vigorous engagement. 